\title{
aniki
}

Revista Portuguesa da Imagem em Movimento

Portuguese Journal of the Moving Image

\section{A Música e o Sagrado na Trilogia de Deus de João César Monteiro}

\author{
José Miguel Nicolau Pinto
}

Instituto de Etnomusicologia - Centro de Estudos de Música e Dança (INET-MD)

zenicop@hotmail.com

https://orcid.org/oooo-0oo2-6454-7123

RESUMO Este artigo incide sobre a presença do sagrado na “Trilogia de Deus”, de João César Monteiro, e sobre a forma como esta é articulada através de elementos e referências musicais religiosas. A aceção de cinema como sagrado, ou seja, como oposto ao profano e, consequentemente, ao "nosso" mundo, tem consequências evidentes na obra de Monteiro. A forma como o mesmo alcança este sagrado é recorrente nos vários meios que constituem o "híbrido medial" que é o filme. A presença musical na "Trilogia de Deus" torna-se uma dessas ferramentas do realizador de alcançar ou, pelo menos, referir, o sagrado nos seus filmes. Este artigo analisa algumas das referências religiosas retorcidas, através das quais César Monteiro procura não o sagrado católico, mas um outro sagrado, que se desenvolve sobre valores que o catolicismo chega a condenar. A principal hipótese defendida é a de que o sagrado na "Trilogia" se desenvolve, pelo menos em parte, a partir das referências musicais religiosas - por um lado, pelo espaço contextual a que são associadas e, por outro, pela subversão desse mesmo espaço. A partir da análise de exemplos particulares, pretende-se desenvolver esta hipótese através de argumentos relativos à interpretação de certos elementos visuais, narrativos e principalmente musicais.

PA LA VRAS-CHAVE Música e cinema; sagrado; João César Monteiro; música religiosa. 
A Trilogia de Deus é um conjunto de filmes realizados por João César Monteiro que nos conta vários episódios da vida de João de Deus, personagem criada e interpretada pelo realizador. ${ }^{1}$ A música dos filmes, quase exclusivamente pré-existente, transporta o espectador/ouvinte para outros contextos relacionados com a sua composição e interpretação. Para além disso, as características físicas dos elementos musicais evocam certos ambientes e emoções, conferindo a cada cena diferentes configurações sonoras. Através destas valências com a música, César Monteiro eleva certos momentos dos filmes ao "sagrado" ou, pelo menos, refere-se a ele. Esta referência ao sagrado, como se verá adiante, surge da evocação ao reportório religioso, por meio da sua evidência ou da sua transgressão

Apesar do protagonismo que a obra de João César Monteiro ganhou recentemente no âmbito académico, a componente sonora dos seus filmes permanece pouco estudada. Este fenómeno pode ser explicado pelo facto de o estudo da música e o som no cinema ser uma preocupação recente da academia. Como afirma Michael Chion (1994, 10), o próprio uso da expressão "ver um filme" revela a tendência para esquecer o fenómeno sonoro inerente à grande maioria dos filmes produzidos. De modo a compreender como é que a música e o som na Trilogia de Deus interagem com o conceito de sagrado e refletir acerca da presença das referências musicais religiosas nessas obras, propomos uma nova "escuta" sobre os três filmes de Monteiro. Incidindo sobre a sua componente sonora, adotaremos, assim, uma abordagem interpretativa inovadora para complementar os trabalhos já existentes sobre a Trilogia de Deus e contribuir para um entendimento mais aprofundado do seu universo ficcional. ${ }^{2}$

Este artigo baseia-se em sistemas analíticos que têm vindo a ser propostos por diferentes estudiosos do cinema. Chion (1994) foi um dos primeiros a proceder a uma reflexão detalhada acerca do processo

\footnotetext{
${ }^{1}$ A denominação deste conjunto de filmes como "Trilogia" não é consenso na comunidade científica. Apesar de ser a denominação mais comum, utilizada no livro organizado por Nicolau (2005) e em diversos trabalhos como o de Navarra (2013), autores como Cunha (2010) ou Areal (2011) referem outros agrupamentos - pentalogia ou tetralogia, respetivamente. No entanto, para este estudo em concreto, usamos o termo "Trilogia" e referimo-nos apenas aos três filmes que a compõem - Recordações da Casa Amarela, A Comédia de Deus e As Bodas de Deus - uma vez que, apesar do personagem João de Deus participar ou ser referido em outros filmes de Monteiro, são estes três que o põem no lugar de protagonista e contam a sua história.

${ }^{2} \mathrm{O}$ presente artigo surgiu dos resultados obtidos na investigação da dissertação de mestrado do autor sobre a música e o som na Trilogia de Deus de João César Monteiro (Pinto 2021). Para uma revisão da literatura sobre a obra de César Monteiro, veja-se sobretudo pp. 2-6.
} 
de assimilação do som no filme, definindo um conjunto de processos de interpretação, exercícios e conceitos-chave que se revelaram especialmente relevantes para a realização deste artigo. Entre eles, destaca-se a análise dos pontos de sincronização entre a imagem e o som, com vista a identificar pontos de maior dinâmica e significado audiovisual. Os ensaios do livro organizado por James Buhler, David Neumeyer e Rob Deemer (2009) propõem um olhar comparativo, permitindo, assim, uma fusão de vários métodos em função dos diferentes objetos fílmicos em análise.

O primeiro filme da Trilogia, intitulado Recordações da Casa Amarela, estreou em 1989. João de Deus, o protagonista, mora numa pensão e apaixona-se pela filha da senhoria, "a menina Julieta" (Teresa Calado), que o rejeita. João de Deus tenta, então, violar a rapariga, mas é interrompido pela senhoria, que o expulsa de casa. Acaba na desgraça, a morar nas ruas de Lisboa. A presença musical neste filme é frequente, desde logo, pelo facto de Julieta ser clarinetista e membro da banda da PSP. Ao longo do filme, ouvem-se vários elementos musicais, principalmente diegéticos, interpretados por Julieta, ou através do rádio a pilhas do protagonista. O segundo filme, intitulado A Comédia de Deus (1995), conta-nos a história de um João de Deus que ascendeu a gerente de uma geladaria onde confeciona gelados dos mais variados “perfumes”. Após ser despedido do seu emprego por se ter envolvido com Joaninha (Cláudia Teixeira) e sodomizado Rosarinho (Raquel Assunção), termina o filme, como em Recordações, desgraçado. Os elementos musicais deste filme são, essencialmente, não diegéticos ou cantados pelas personagens. Destaque-se aqui a presença da obra de Haydn, essencialmente de temática religiosa. Por fim, As Bodas de Deus (1999), o último filme da Trilogia, é o que se apresenta com menos elementos musicais. João de Deus começa mendigo, eleva-se a barão, é preso e acaba solto da prisão, esperado por Joana (Rita Durão), que lhe havia prometido devoção eterna. Apesar dos poucos elementos musicais, neste último filme surgem momentos pontuais em que a música se torna protagonista, com apresentações de grandes trechos sobre momentos visuais pouco dinâmicos. 
O realizador tece a narrativa dos três filmes através de um emaranhado de elementos e citações característico da estética cesariana. ${ }^{3}$ Os elementos musicais pré-existentes são (re)contextualizados por César Monteiro, que faz deles seus, moldando-os à sua obra. Assim, a forma como as referências musicais religiosas são retorcidas para alcançar o sagrado cesariano torna-se numa parte expressiva da Trilogia, a qual merece maior destaque na interpretação destes filmes.

Neste artigo, após uma contextualização teórica da presença do sagrado na cinematografia do realizador, resultado da articulação das visões de vários autores e do próprio César Monteiro, examinaremos referências musicais religiosas na Trilogia de Deus. A partir desta análise, conclui-se que essa presença religiosa se expressa, por um lado, pelo seu caráter e, por outro, pela sua subversão e transgressão. Nalguns exemplos há uma relação de afinidade entre o reportório musical religioso e o cariz visual e narrativo da cena. Noutros, é na contrariedade que estes se encontram e se transgridem mutuamente.

\section{Uma primeira abordagem: possibilidades do "sagrado" na Trilogia}

As valências formativas do objeto fílmico tornam este meio especialmente recetivo às tentativas de captação do transcendente ou do sagrado. O cinema constitui-se como um lugar que permite a formação de uma nova realidade que à primeira vista parece ser criada à semelhança da "nossa", mas que surge, por vezes, completamente distorcida. É esse o caso na Trilogia de Deus, em que César Monteiro/ João de Deus cria o seu próprio universo, onde "criador e criatura [se fundem] em absoluto, permitindo que o cinema de Monteiro se estabeleça como um espelho no qual a si mesmo se reflete" (Costa 2016, 2).

Inês Gil, sobre a afinidade entre o sagrado e o cinema, considera que ambos têm origem no real, sendo que o cinema é "uma arte que parte da imagem do real para o desconstruir, e que ao recriá-lo com a sua própria ordem, lhe dá um novo sentido" (Gil 2012, 197). Questionando

\footnotetext{
${ }^{3}$ A referência a outras obras de arte é um dos pilares estilísticos da cinematografia de Monteiro. Encontra o seu expoente máximo no filme Que Farei Eu com esta Espada (1975), construído através da montagem alternada entre filmagens do realizador e trechos fílmicos pré-existentes, nomeadamente do filme Nosferatu de Murnau. Na Trilogia, são várias as referências dialógicas, pictóricas, musicais ou mesmo estilísticas a outras obras ou autores. Para um aprofundamento desta questão, veja-se García Manso (2012) e Giarrusso (2013).
} 
as conceções de um "sagrado contemporâneo", a autora enfatiza a amplitude do conceito deste termo reconhecendo que a busca pela sua expressão nas artes vai além de uma "iconografia tradicional religiosa" e pode ser (re)criada de várias formas (Gil 2012, 199). Nesse sentido, a mesma considera o processo de sacralização no objeto fílmico particularmente original: este, ainda que partindo do real, "utilizando o grande plano, o movimento da câmara ou outros meios técnicos", consegue "tornar visível o invisível, para o tornar imediato e presente, na experiência do espetador” (Gil 2012, 210).

Para Pedro Camacho Costa, o sagrado em Monteiro não surge, como é mais comum, apenas associado à criação, mas também à "contracriação" (Costa 2016, 2). O sagrado, que é o cinema, como defende o próprio César Monteiro (2005a), está relacionado com uma série de paradoxos que culminam na dicotomia criação/destruição em que o filme, para além de ser capaz de formar uma realidade, é também "uma violência do olhar, uma profanação do real” (Monteiro 1974). É na descontinuidade da construção fílmica, que surge como resultado de uma panóplia de elementos transtextuais - na aceção de Gérard Genette (1997) -, que se encontra a desconstrução do cinema de Monteiro que, à partida, é edificado de forma fraturada (Costa 2016, 20). Também a fusão do criador com a criatura torna difusos os seus papéis e enfraquece as barreiras entre os dois mundos - realidade e cinema - que se pretendem destruir mutuamente numa constante tentativa de unificação.

O sagrado em César Monteiro atinge-se, entre outras formas, através de rituais. No caso da Trilogia, estes são celebrados pelo "seu duplo" (Monteiro 2005b, 413), João de Deus, e envolvem "jovens raparigas [que] se submetem em altares” (Maia 2013, 103). Segundo Catarina Maia, o cinema de Monteiro move-se nos campos do sagrado e do transcendental e quando "entra contrariado [no] campo profano é só para melhor o poder destruir por dentro, o fazer implodir" (Maia 2013, 103), como, por exemplo, no caso das regras sanitárias da geladaria de A Comédia de Deus, onde o próprio Sr. João faz questão de frisar, repetidamente, que não "cumpre escrupulosamente nenhuma" (Maia 2013, 104). No seu mundo, as regras do profano existem para serem transgredidas.

A interação entre "mundo profano" e "mundo sagrado" é abordada de forma especialmente relevante por George Bataille (1995) em $O$ Erotismo. Para o autor, o "transgredir" constitui, justamente, a esfera do 
sagrado - ultrapassando o profano utilitário das proibições - e o erótico que, por sua vez, configura-se como a expressão máxima da transgressão. O erótico, portanto, é alcançado por César Monteiro através "[d]as frechas das portas e [d]os buracos de fechaduras, através do som, de reflexos em espelhos, ou de sombras projetadas nas paredes" (Maia 2013, 105). O ato sexual é filmado diretamente apenas na cena entre João de Deus e Elena (Joana Azevedo) em As Bodas de Deus. Por exemplo, é o som que, no segundo filme do conjunto, vem detalhar o ato sexual protagonizado por João de Deus e Rosarinho na geladaria, do qual só se vê na imagem o que transparece através da porta da casa de banho (1:09:47 - 1:10:40). O local onde se passa a cena enfatiza o caráter transgressivo do ato, local esse "onde antes afirmara, por exemplo, ser sacrilégio andar em roupa interior” (Maia 2013, 104).

Outra forma de expressar o sagrado, e a que será abordada neste artigo, é a de enfatizar as conotações divinas das figuras e dos objetos através de evocações do sagrado religioso. Ora, a subversão da religião que já é (ou deveria ser), segundo Roger Caillois, a entidade administrativa do sagrado (Caillois 2001, 20), constitui um ápice da transgressão em Monteiro e, assim, uma elevação do filme ao patamar do sagrado. ${ }^{4} \mathrm{~A}$ iconografia, sonografia e a dialógica religiosas constituem os pilares do estilo simbólico-cinematográfico da Trilogia e enfatizam o destaque dado ao sagrado nos filmes.

Numa primeira análise superficial, o nome do protagonista já tem em si próprio uma simbologia religiosa:

Unindo o seu nome (João) ao do Criador (Deus), Monteiro deifica-se, clamando para si o papel de cineasta demiurgo, um Deus caído ou apoteótico, transgressor e deificador, demoníaco e seráfico, entre a criação e a contracriação de si mesmo, num gesto esquizofrénico. (Costa 2016, 2)

A presença de "Deus" está também no nome da Trilogia e de dois dos filmes que a compõem - A Comédia de Deus e As Bodas de Deus. Na iconografia dos filmes surgem várias referências ao sagrado cristão,

\footnotetext{
${ }^{4}$ A relação entre o realizador e o sociólogo já tinha sido apontada por Sidónio Paes, que refere os dois modos antitéticos do sagrado - o sublime e o terrível - definidos por Caillois. Segundo este autor, João César Monteiro "oscila entre ambos, como polos de atracção-repulsão" (Paes 2005, 44).
} 
entre elas o anjo ao lado de João de Deus no seu encontro com a mãe, em Recordações, ou o "cupido angelical" (Giarrusso 2013, 203), que se vê atrás da Joaninha na cerimónia champanhesa, n’A Comédia. Estes, em conjunto com outros elementos, como o enquadramento e os gestos das personagens, criam uma atmosfera de "conotações sagradas [...] como se de uma cerimónia religiosa se tratasse” (Giarrusso 2013, 203). Também nos diálogos entre as personagens constam várias alusões ao universo religioso - "assim se tiram os pecados do Mundo" ou "a sarça ardente". No entanto, são as referências religiosas dos elementos musicais que constituem o tema central da minha análise.

A referência religiosa presente na música escolhida para certos momentos dos filmes confere a estes momentos - e, num sentido mais amplo, aos objetos, às personagens ou aos espaços narrativos que estes contêm - uma conotação sagrada, em conjunto com outros elementos. Através da música ou da sua significação simbólica, César Monteiro consegue transcender o profano e evocar o sagrado ao longo da Trilogia.

\section{Recordações da Casa Amarela}

No filme Recordações da Casa Amarela há apenas uma referência religiosa musical, quando João de Deus visita a sua mãe (Maria Ângela Violeta), que está a limpar as escadas (0:39:22 - 0:42:02). Sobre esta imagem, ouve-se o Stabat Mater (RV 621), em fá menor, de Antonio Vivaldi. A obra, um hino de adoração à Virgem Maria, parece constituir uma representação musical da mãe de João de Deus, também ela uma "mater dolorosa", desprezada pelo filho que a vai visitar para lhe pedir dinheiro.

O elemento musical presente na cena constitui-se pela introdução instrumental e pela primeira estrofe do Stabat Mater. O andamento Largo e a homorritmia das vozes inferiores criam um ambiente sonoro particularmente reflexivo. As colcheias em stacatto remetem para e antecipam os passos de João de Deus a subir as escadas, ainda que não estejam plenamente sincronizadas com estes. Esse padrão rítmico repetitivo num registo grave aumenta o "peso" com que o personagem sobe a escadaria e, assim, confere à cena uma maior seriedade. As partes dos violinos estão organizadas numa espécie de canon fugado. O gesto melódico está recheado de intervalos de grande registo que, 
embora imediatamente compensados, conferem uma tensão maior ao momento do filme.

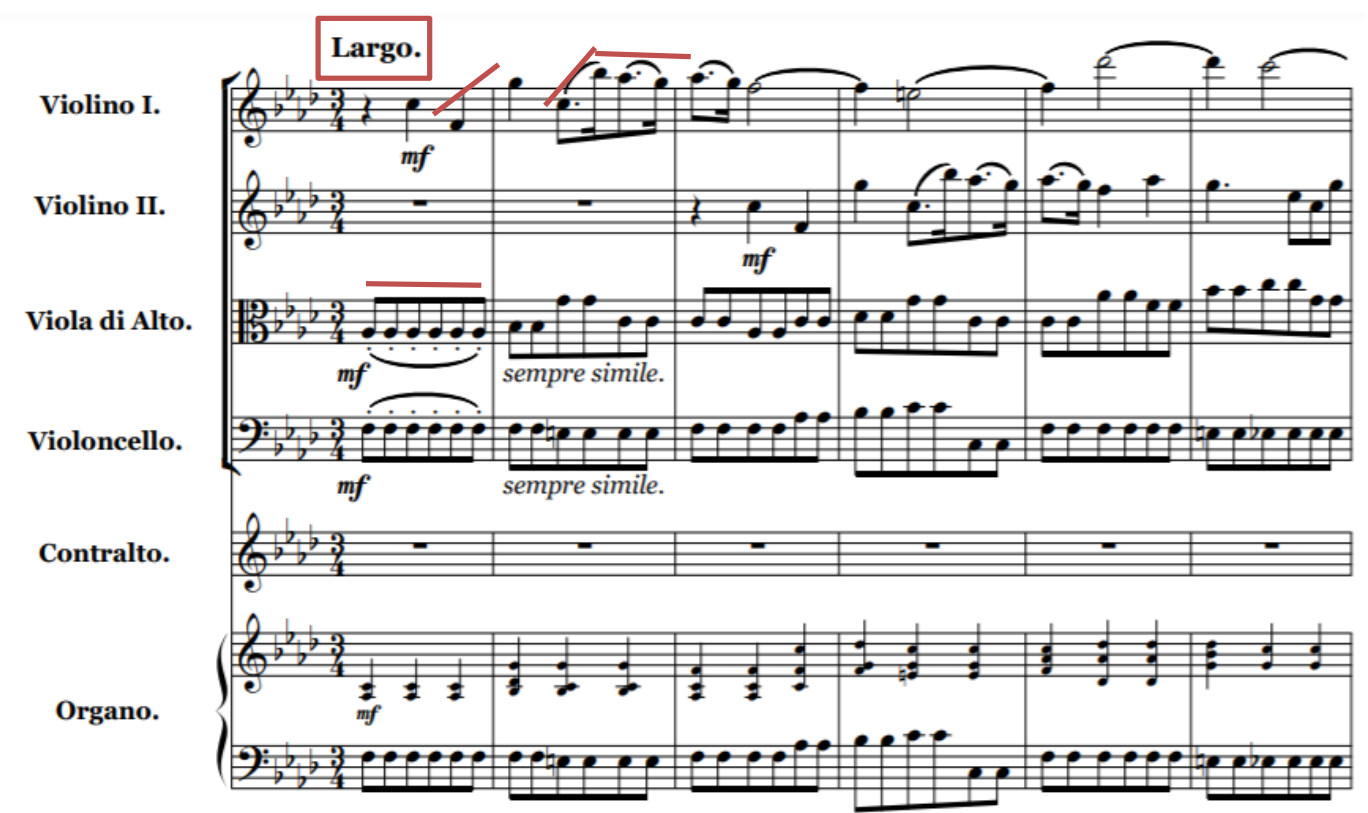

Exemplo 1 - Antonio Vivaldi, Stabat Mater (c. 1727), "Stabat Mater Dolorosa”, compassos 1 a 6. Andreas Schein (ed.), 1997. Início do elemento musical.

A voz solista entra quando João de Deus se encontra a meio do primeiro lanço de escadas - uma voz num registo agudo, por isso associada ao feminino, tema da cena e, como argumentado mais adiante, do filme em questão. Esta voz é apenas acompanhada pelo baixo contínuo, executado pelo órgão e pelo violoncelo, dotando a cena de uma pureza e simplicidade que cria uma atmosfera sagrada, "hierática" como lhe chamava Giarrusso $(2013,241)$. Tal atmosfera é enfatizada também pela lentidão dos passos de João de Deus, pela lentidão do movimento de câmara, pela figura do anjo e pela escadaria que, de alguma forma, nos remete também para a elevação, associada, inevitavelmente, a uma sacralidade. Todos estes elementos contrastam com a mãe de João de Deus, que conhecemos no plano seguinte. A figura divina pela qual o espectador esperava é, afinal, uma velha doente, sujeita a trabalhar para os outros e a dar o pouco que tem ao seu filho. O elemento musical desvanece-se em fade out, disfarçado 
pelas palavras do protagonista, que chama pela mãe no final do primeiro verso.

\section{Fade out}

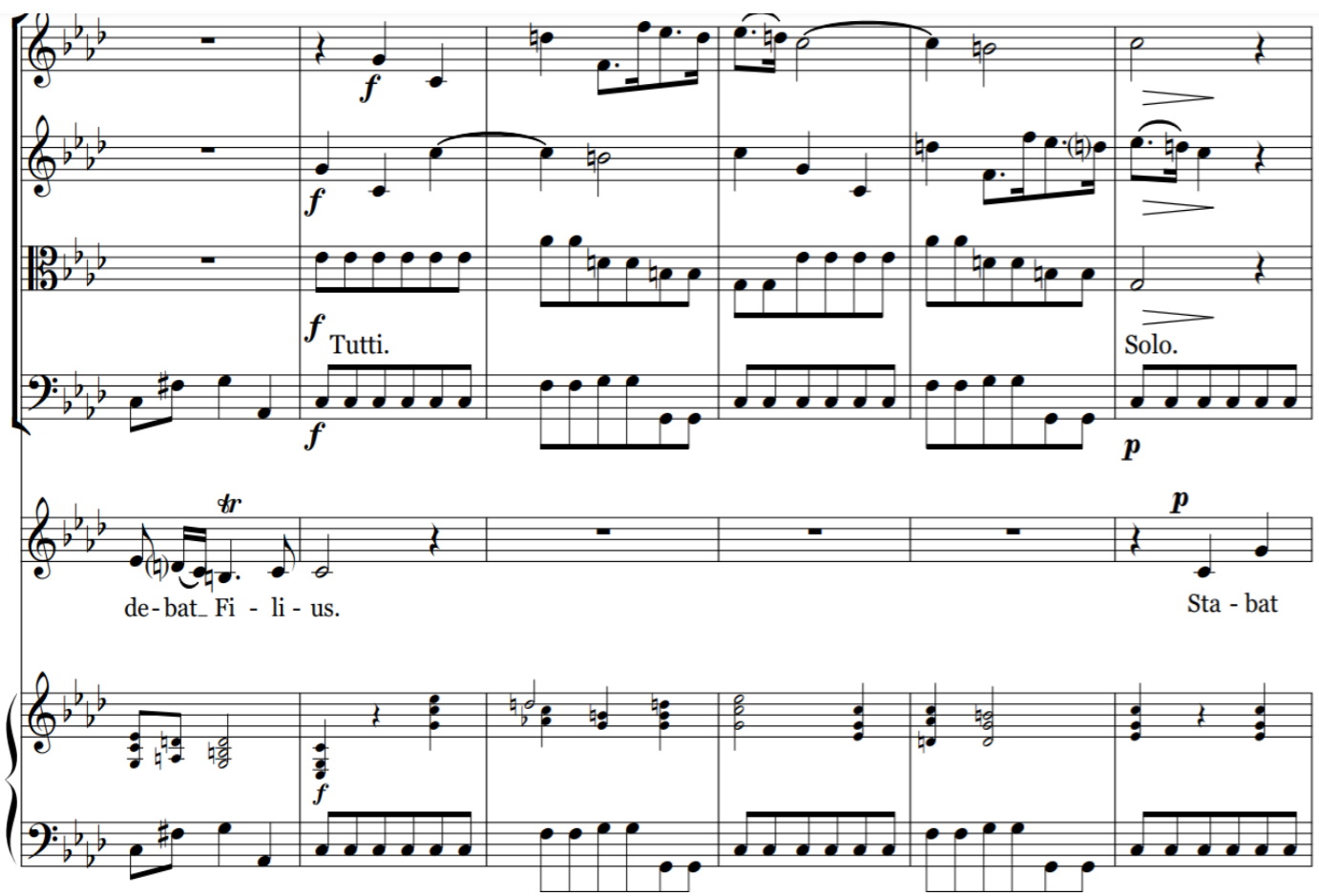

Exemplo 2 - Antonio Vivaldi, Stabat Mater (c. 1727), "Stabat Mater Dolorosa", compassos 20 a 25. Andreas Schein (ed.), 1997. Final do elemento musical.

Para Bénard da Costa, a mãe é o tema central deste primeiro filme da Trilogia:

O travelling do rio, não acaba, por acaso, na Igreja da Madre de Deus: uma das mais belas igrejas quinhentistas de Lisboa. Também não é por acaso que a sequência seguinte se passa numa capela, dedicada a Nossa Senhora, e que a primeira imagem que vemos nela é a de Nossa Senhora. Vemos mesmo a Nossa Senhora antes de vermos João de Deus. É que Recordações da Casa Amarela é também - eu tenderia a dizer é sobretudo - um filme sobre a Mãe. (Costa 2005, 385)

A figura maternal encontra-se na igreja, na leitaria (centrada na venda do produto materno), em Mimi (Sabina Sacchi com voz de Inês Medeiros), também ela mãe, em Violeta (Manuela de Freitas), mãe de 
Julieta e na mãe do próprio João de Deus. Esta figura, como centro gravitacional das Recordações, é sacralizada através da divinação das várias personagens que a personificam. Neste caso, temos a mãe de João de Deus, em parte, sacralizada através do elemento musical ouvido no início da cena, referência ao rito católico, mas também diretamente à figura da Virgem Maria, mãe de Jesus Cristo.

A presença do anjo ao lado de João de Deus enfatiza este caráter sagrado da figura da mãe que se encontra num nível superior, no cimo das escadas. Paradoxalmente, quando a "Madre de Deus", como lhe chama Ferdinando, ${ }^{5}$ surge no plano, está agachada limpando as escadas, velha e com problemas de saúde, como menciona no diálogo. A ideia de dor, presente no texto da obra musical que narra o sentimento da mãe de Jesus quando o vê crucificado, está presente no filme de uma forma diferente. Nesta cena temos, por um lado, a divinação da figura da mãe com os elementos sacros que, mesmo involuntariamente, lhe associamos e, por outro lado, assistimos ao desprezo com que é tratada pelo seu filho e pela vida, que a obriga a limpar as escadas por um salário que lhe é "sugado" pelo "vampiro" João de Deus (Nogueira 2010, 209). Esta dicotomia é referida por Camacho Costa como um "comportamento abominável" que "contrasta com a sacralidade da figura maternal, da banda-sonora, da situação” (Costa 2016, 56) e Giarrusso refere que "a conduta de João de Deus é abjeta e escabrosa e contrapõe-se ao caráter hierático da banda sonora” (Giarrusso 2013, 241). Ambos os autores concordam que os elementos da narrativa são contrapostos com este elemento musical que, embora contraditório, consegue fazer conotar a cena com uma sacralidade, assim como a própria personagem "Madre de Deus", o que constitui um choque ainda maior com o comportamento de João de Deus, amplificando a intensidade da cena.

\footnotetext{
${ }^{5}$ Personagem do filme interpretada por João Bénard da Costa. Participa apenas numa cena, passada num restaurante, em que pede a João de Deus que lhe faça um trabalho de fotografia.
} 


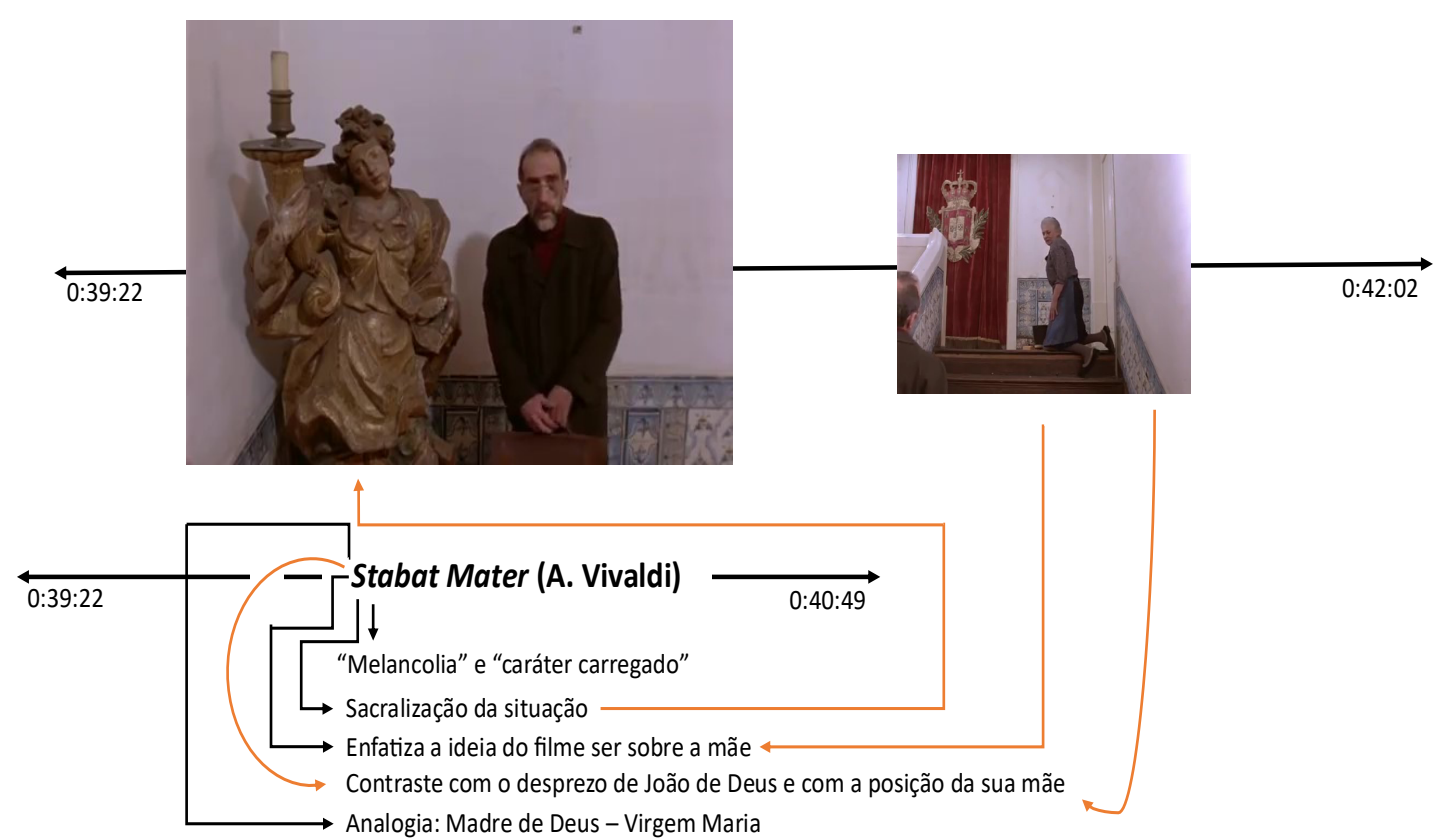

Gráfico 1 - Relação música - sagrado na cena em que João de Deus visita a mãe das Recordações da Casa Amarela.

\section{A Comédia de Deus}

O sagrado n' A Comédia de Deus surge intimamente associado ao gelado que está para João de Deus como o cinema está para César Monteiro. É nesta duplicidade que assenta, em primeira instância, o reflexo que enfraquece as barreiras entre o mundo real e o mundo de João de Deus. Inicia-se, assim, a analogia: César Monteiro cria um universo onde habita João de Deus, dono d'O Paraíso, onde produz as suas iguarias e impõe as suas regras com o maior rigor (sendo que ele próprio as transgride ao longo do filme). O papel de criador está em César Monteiro e no Sr. João - o primeiro cria o filme e o segundo o gelado. Quando João de Deus e D. Antónia (Glicínia Quartim) contam a história da evolução do gelado é proposta uma analogia entre esta e a história do cinema, nomeadamente através da alusão aos sorvetes franceses e italianos e ao domínio do ice-cream americano, "atualmente popularizado por toda a parte" (veja-se os minutos 0:34:48 - 0:35:19 e 0:46:44 - 0:48:35). Para César Monteiro, "o sagrado é o cinema" (Monteiro 2005a, 359) e o gelado n'A Comédia de Deus é dotado de conotações divinas. 
Outra das figuras divinizadas ao longo do filme é a mulher, também com as suas valências criadoras, como João de Deus enfatiza nas palavras: "nunca te esqueças que um dia também tu serás mãe". É em honra das várias personagens femininas que João de Deus procede a vários rituais, em sua casa ou n'O Paraíso, enfatizando o sagrado do feminino ao qual foi também concedido o dom de criar. N'A Comédia de Deus, a mulher, "centro gravitacional em torno do qual gira todo o universo da Trilogia" (Giarrusso 2013, 202), é protagonista de "autênticos cerimoniais dedicados à beleza do corpo feminino" (Giarrusso 2013, 202). No entanto, neste processo de sacralização não só criador, mas também subversivo, vemos a mulher humilhada, sodomizada e violada pelo protagonista. Os espaços sagrados de criação (do gelado, por exemplo), são também espaços de violação, transgressão e destruição. Encontramo-nos perante um sagrado destrutivo que diviniza a figura da mulher, mas também a inferioriza, destruindo a sua própria divinização e reiterando a dicotomia criação/destruição apresentada anteriormente.

A Comédia de Deus inicia-se com a apresentação do genérico pela voz do filho do realizador (0:00:11 - 0:00:17). A relação pai/filho é paralela, para César Monteiro, à relação realizador/cinema e, na perspetiva de Camacho Costa, o segundo representa um dos "outros nomes para a criação cinematográfica” (Costa 2016, 59). Após a apresentação do genérico, ouve-se o Intonatio das Vespro della Beata Vergine de Claudio Monteverdi - "Deus in auditorium" - sobre a imagem da Via Láctea em rotação (0:00:19 - 0:02:10). A utilização de uma música de caráter litúrgico ganha, por si só, conotações sagradas neste momento que, ainda que não pertença diretamente à narrativa, a precede e, por isso, a condiciona. $\mathrm{O}$ facto de a imagem constituir um quadro com um movimento repetitivo leva o espectador/ouvinte a prestar uma maior atenção ao som, caracteristicamente dinâmico e com uma grande variedade tímbrica e contraste, principalmente entre as secções corais e os ritornellos.

Este elemento musical é amplamente diferente do Stabat Mater anteriormente apresentado. No entanto, o adjetivo que Giarrusso lhe confere é o mesmo. Mais uma vez, o autor $(2013,25)$ considera que o elemento musical garante à cena - na qual a dinâmica é proporcionada principalmente pela música - um caráter "hierático". Como já se constatou, o contexto da composição e interpretação das Vésperas de Claudio Monteverdi contribui para esta possível significação. Também 
olhando para o caráter majestoso da obra, escrita para coro e orquestra e, assim, com um amplo registo harmónico, melódico e uma grande massa sonora, se antecipa a entrada de algo sublime, extraordinário, enfatizando o caráter sagrado da cena. A primeira parte da obra ouve-se no início do filme e essa grandiosidade sonora constitui um enquadramento musical que cativa a atenção do espectador/ouvinte.

A parte do coro é homorrítmica e melodicamente estática (cada voz repete a mesma nota seguindo o mesmo padrão rítmico), constituindo, então, a harmonia base da secção, toda sobre o mesmo acorde - ré maior. As notas são dobradas em oitava pelas diferentes vozes e criam, assim, uma massa coral densa que se reflete na constituição sonora cheia da parte musical.

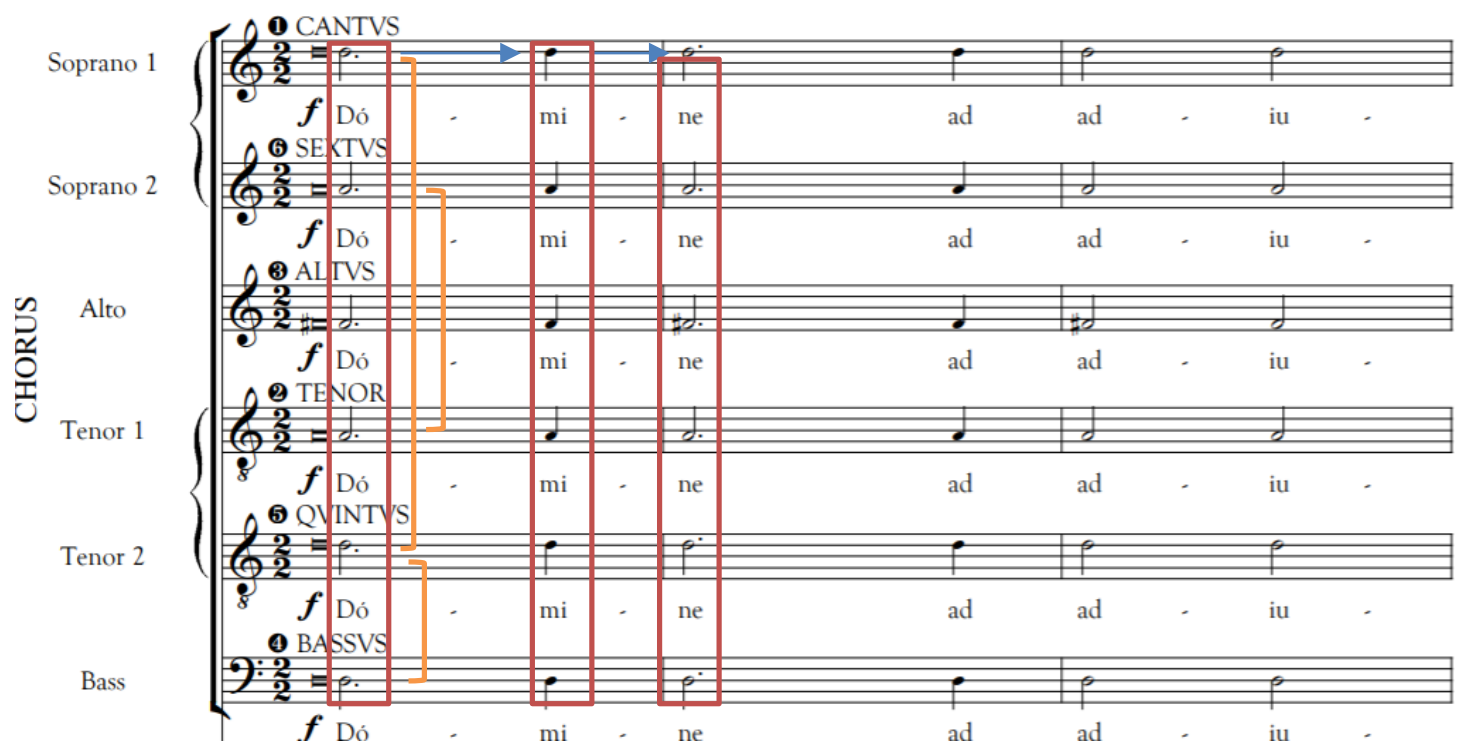

Exemplo 3 - Claudio Monteverdi, Vespro della Beata Vergine (1610), "Domine ad adiuvandum", compassos 1 a 3. Philip Legge (ed.), 2006. Parte coral.

A parte instrumental é melodicamente mais rica. É caracterizada por um motivo melódico rápido em semicolcheias numa escala ascendente que culmina na nota lá com um valor de dominante (tensão). Essa insistência nas escalas ascendentes enfatiza, com clareza, a ideia de elevação, de subida aos céus, ainda associada ao texto litúrgico que acompanha a melodia. O motivo mencionado surge nas várias vozes em estilo fugado, dando uma perceção de sucessiva não resolução, atrasando a distensão melódica. Auditivamente, e de forma figurada na partitura, o movimento ascendente remete para as alturas. No 
compasso 9, inicia-se uma cadência intermédia apenas instrumental para, após uma suspensão, retomar o estilo fugado das partes instrumentais, oposto à homorritmia das vozes do coro.

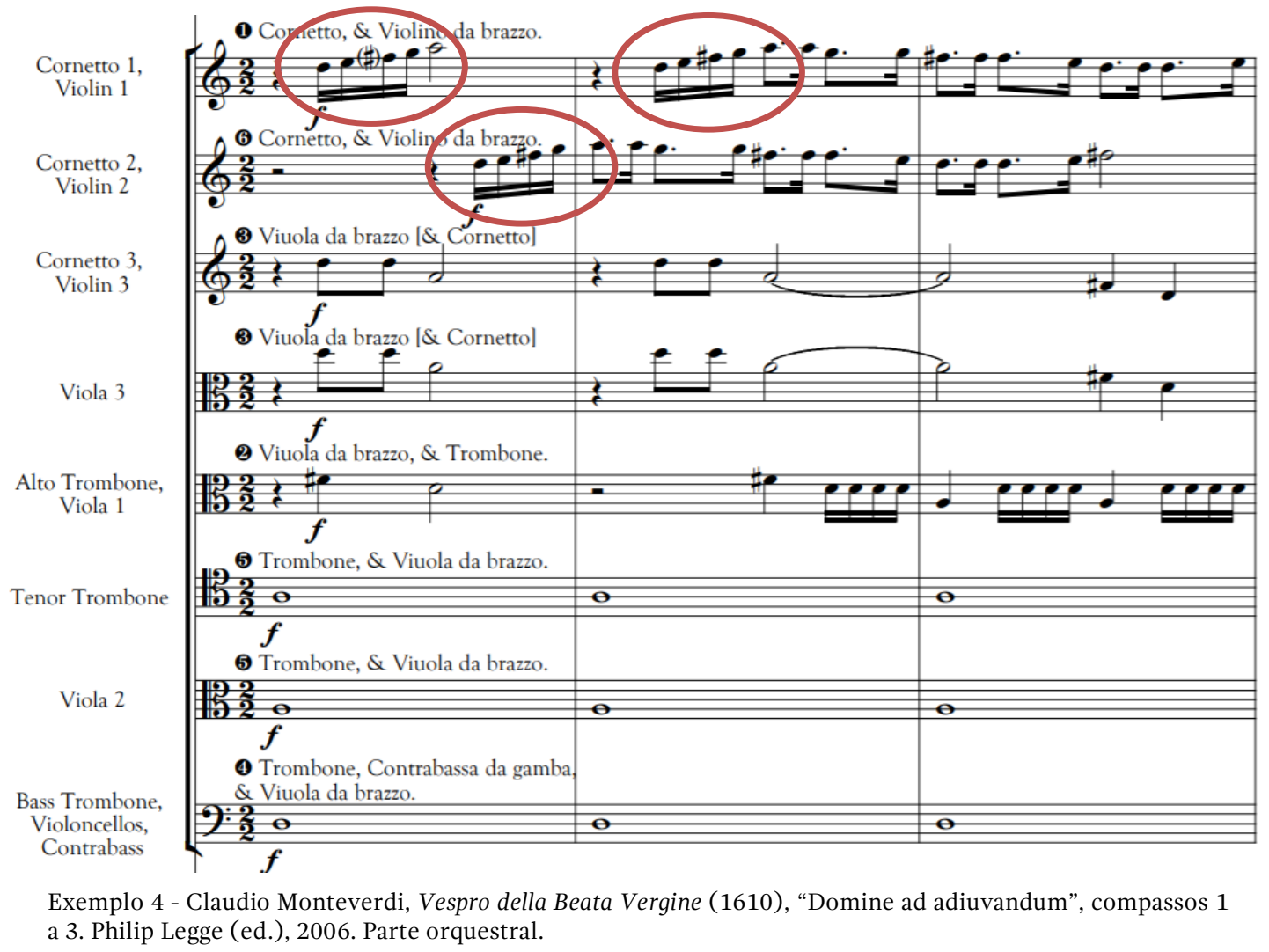

No final da parte musical, a partir do compasso 42 , inicia-se a cadência do Intonatio das Vésperas. Nesta cadência, as partes corais, mantendo a simultaneidade rítmica, deixam de ser estritamente harmónicas para, em estilo de coral, passarem a ser responsáveis pela melodia.

Neste caso, o simbolismo da imagem parece constituir parte da chave para a compreensão deste momento do filme. A conexão com o sagrado passa também pela imagem da Via Láctea que, logo em primeira instância, se refere ao cosmos, aos astros e a todas as suas conotações que, talvez pelo desconhecimento que as envolve, são sagradas. A música como referência litúrgica também evidencia esse caráter do qual este momento de pré-ação fica dotado. Por outro lado, o começo das Vésperas vem dar início ao filme de Monteiro e este excerto musical, que constitui um pedido de auxílio a Deus, serve agora como um pedido de auxílio para João de Deus, ele também criador de um 
universo que acaba por desabar. Consiste, por isso, num presságio do que sucederá ao longo do filme.

Da Via láctea podemos deduzir a representação cósmica do leite, ingrediente central na criação do gelado, mas também associado à maternidade e, assim, à criação. Com a Via Láctea surgem, então, representações de dois dos símbolos centrais d'A Comédia que, conforme sugerido acima, são os principais alvos deste processo de divinação ao longo do filme. Com a representação da galáxia como representação simbólica da mulher e do gelado, temos a música a deixar demarcadas as suas relações com o sagrado através da evocação litúrgica.

Camacho Costa propõe uma outra analogia, em que a galáxia representa a criação demiúrgica que, por sua vez, é refletida na criação cinematográfica em que Monteiro/João de Deus se assume como criador do universo que vai ser apresentado. Nesse sentido, a música, para além de remeter para o divino, remete também para João de Deus, com o seu próprio nome já permeável a essas relações (Costa 2016, 59). A partir daí, considera-se que César Monteiro, realizador demiurgo, e João de Deus, duplo de César Monteiro, criaram o universo em uníssono para depois se separarem em autor e ator e viverem diferentes papeis. Assim, neste prelúdio cinematográfico, podemos ver uma introdução ao universo de Monteiro, em que, com a abertura musical das vésperas, se dá início ao “ofício divino” protagonizado por João de Deus. É também nesta ideia que assenta uma das perspetivas de Giarrusso sobre o início d'A Comédia: é "como se Monteiro nos convidasse a assistir à sua criação, apresentando-nos o universo em que a sua personagem imporá [...] o reino dos seus desejos mais íntimos" e onde a música "vem confirmar as qualidades demiúrgicas de Monteiro, conferindo à imagem uma dimensão hierática, como se se tratasse da génese do mundo pela mão de Deus" (Giarrusso 2013, 25). Noutra perspetiva, o autor considera que a imagem da galáxia vem destacar a "consubstancialidade do autor na obra", pondo "em evidência o caráter relacional com que se forma o universo" (Giarrusso 2013, 26-27). Assim, através da analogia com o universo, demonstram-se "as capacidades do Uno se manifestar na multiplicidade" (Giarrusso 2013, 26-27), como faz Monteiro ao longo da Trilogia com a sua presença 
múltipla em figuras como João de Deus e Lívio ${ }^{6}$ (e, na esfera exterior [ou não] ao universo do filme, Max Monteiro e o próprio Cesar Monteiro). E ainda na mesma linha de pensamento:

a imagem sideral de A Comédia de Deus coincide com uma conceção do espaço semiótico em que os diferentes corpos textuais, assim como acontece com os siderais, são responsáveis pela geração de novos elementos semióticos. (Giarrusso 2013, 27)

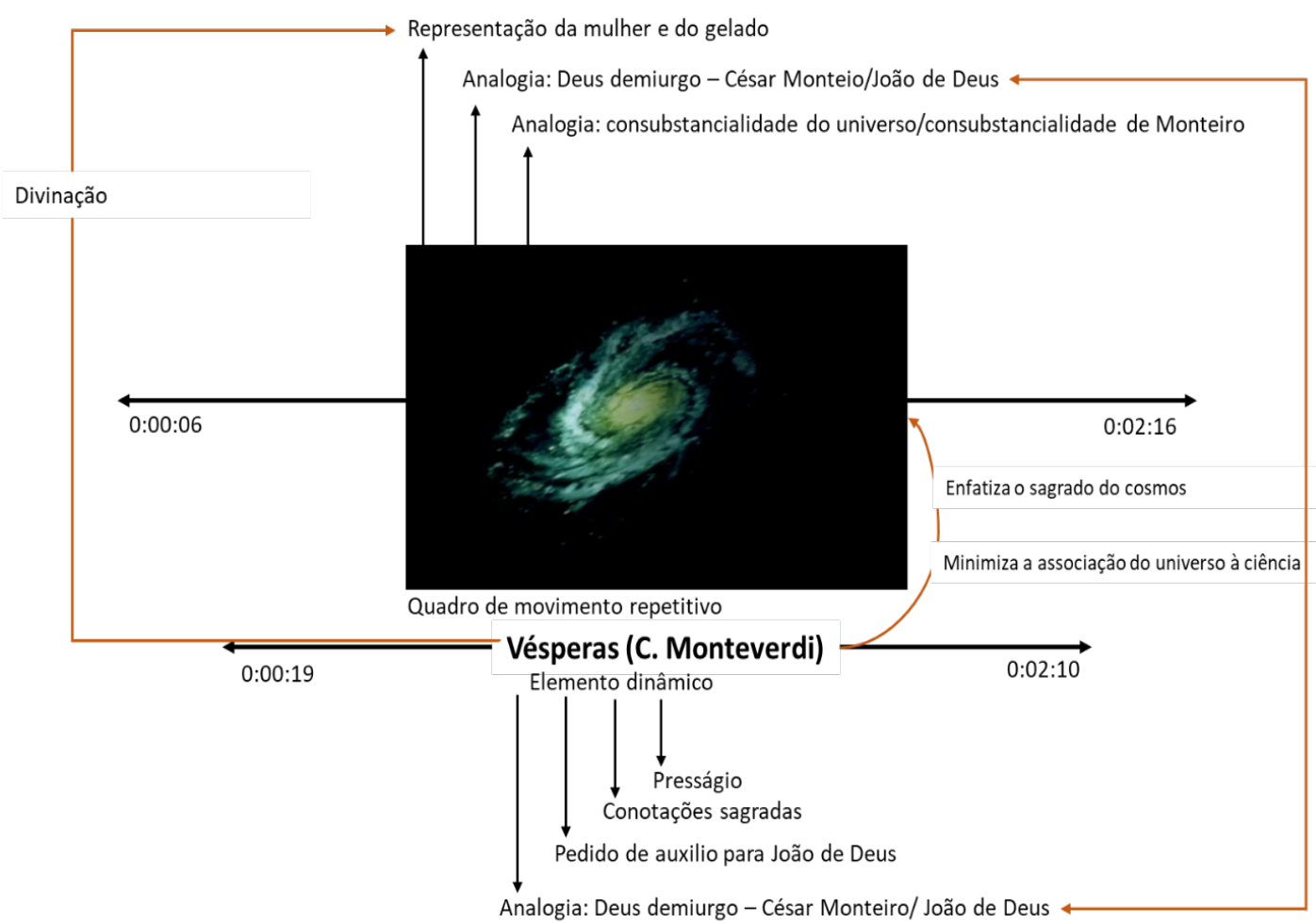

Gráfico 2 - Relação música - sagrado nos créditos iniciais de A Comédia de Deus.

\footnotetext{
${ }^{6}$ Personagem interpretada por Luís Miguel Cintra, primeiro no filme Quem espera por sapatos de defunto morre descalço (1971) - com a voz dobrada por João César Monteiro - e depois em Recordações da Casa Amarela. Lívio encontra-se com João de Deus no asilo psiquiátrico e essa interação dos dois personagens constitui-se como "uma espécie de corpo e alma, corpo e voz que se vão encontrar" (Costa em Cineluso, 2009). Luís Miguel Cintra reaparece n'As Bodas de Deus, primeiro como Enviado de Deus e depois como doente no Asilo, mas, aí, já não reconhece o protagonista.
}

aniki Ensaios | Essays 
Outra referência musical litúrgica que, como no exemplo acima, transcende o campo musical com as possíveis significações que confere à imagem, é o "Agnus Dei” da Missa Sanctae Caeciliae, de Joseph Haydn - na cena em que João de Deus vai ao talho do pai de Joaninha (o:23:59 - 0:24:30). A música ouve-se sobre um plano da cabeça de um cordeiro e termina, abruptamente, com a degolação do animal. Como uma premonição do que acontecerá com João de Deus, que irá ser castigado pelo mesmo talhante que degola o cordeiro, a cena assume conotações religiosas através da música - a imagem deixa de ser de um cordeiro para ser do "Cordeiro de Deus". Bénard da Costa considera que "nesse plano estarrecedor, quando ainda nada sabemos do papel futuro do pai de Joaninha na história, prenuncia-se o sacrifício de João de Deus, a sua via crucis" (Costa, sem data, 107). A alusão à "via crucis" não deixa de remeter para este estatuto sagrado do próprio João de Deus que, como Jesus Cristo, abala as regras da sociedade que acabará por condená-lo. $\mathrm{E}$, de facto, no final do filme, no segundo encontro entre o talhante Evaristo e João de Deus, "o cordeiro sacrificial é o protagonista que de leites, em deleites, banhou a filha do sangrento carniceiro" (Costa 2016, 66).

No filme, o excerto começa no início do "Agnus Dei” com os violinos que, ao longo de todo o elemento, seguem o mesmo padrão rítmico em conjuntos de quatro semicolcheias e um desenvolvimento melódico feito essencialmente de notas repetidas. Assim, constituem o acompanhamento da voz que será a parte solista. Este modelo de acompanhamento isorrítmico resulta numa temporalidade muito característica da imagem. O tempo de ação do filme, normalmente, passa mais rápido que o tempo real, uma vez que no cinema ficcional costumam evidenciar-se os momentos de maior relevo para a narrativa. Muito comumente, os elementos musicais e o seu caráter ritmicamente dinâmico constituem uma das ferramentas usadas para essa "aceleração" temporal. No entanto, podem também contribuir para o efeito contrário, como é o caso do presente exemplo. O excerto do "Agnus Dei”, que se ouve sobre a imagem da cabeça do cordeiro, e a constância das figuras rítmicas, que dão movimento à obra musical, aproximam o tempo de ação do tempo real. Assim, confere-se à imagem e à cena geral uma maior importância e ambas passam a estar presentes na memória do espectador/ouvinte durante o resto do filme, nomeadamente no reencontro de João de Deus com o talhante, em que o primeiro se converte em cordeiro. 
A voz entra na segunda metade do segundo compasso, com um ritmo lento (em contraste com as semicolcheias do acompanhamento). $\mathrm{O}$ gesto melódico da parte vocal é descontínuo com intervalos de grande registo que, em oposição ao acompanhamento simples, trazem à obra uma instabilidade que passa também para o caráter emocional da cena. A tensão conseguida através do elemento musical vai de encontro à imagem chocante da cabeça do cordeiro, conferindo à cena o caráter "estarrecedor" sobre o qual Bénard da Costa escreve (Costa, sem data, 107). O final do elemento, sincronizado com o som da faca que degola o cordeiro, surge após um intervalo melódico de décima segunda e, com este amplo registo, essa parte torna-se o ápice do excerto ouvido. É sobre esse momento de ápice musical que César Monteiro opta por colocar o ápice pictórico e da narrativa - o momento da degolação do animal, simbolizando o sacrifício do cordeiro.

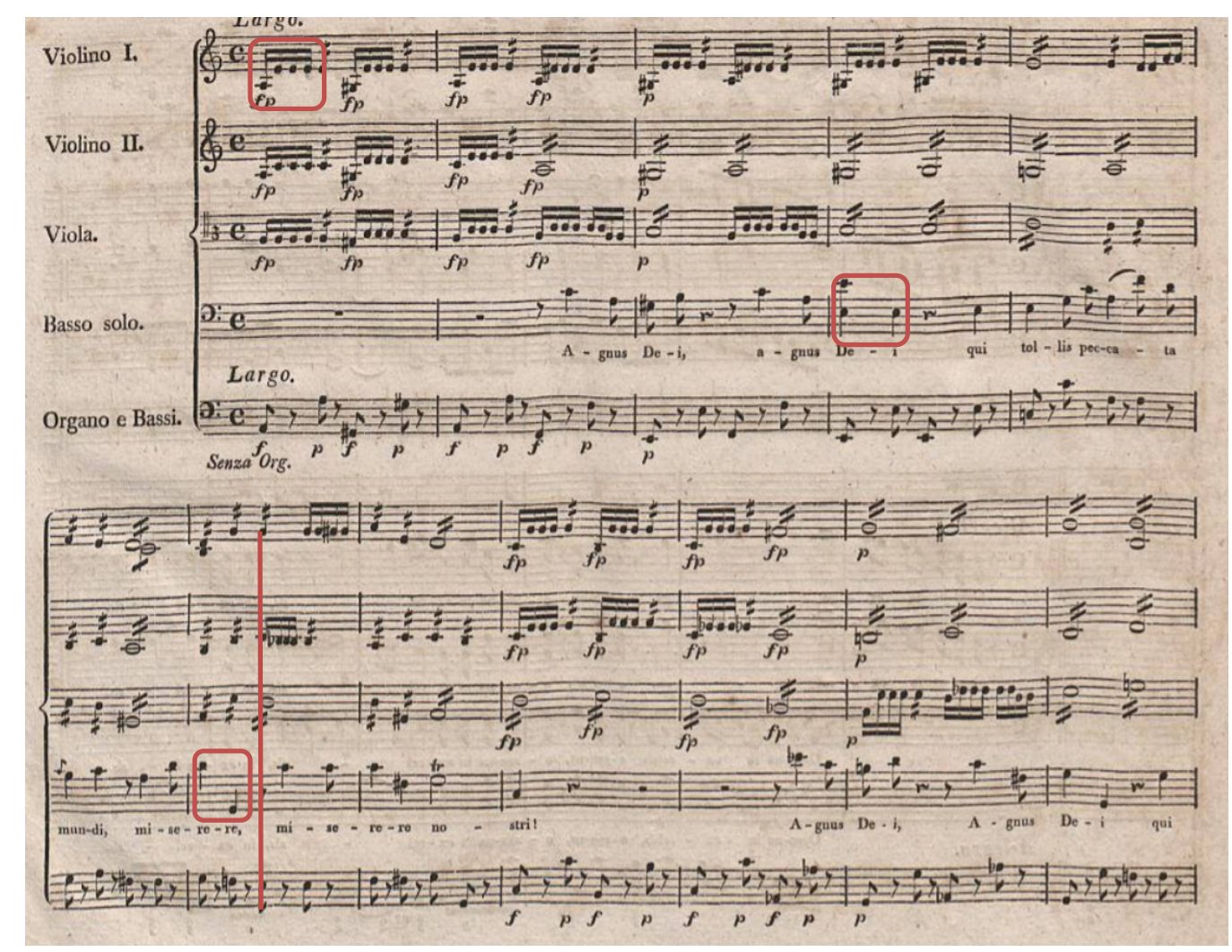

Exemplo 5 - Joseph Haydn, Missa Sanctae Caeciliae (1811), "Agnus Dei", compassos de 1 a 12. Leipzig: Breitkopf \& Härtel, s.d.. 


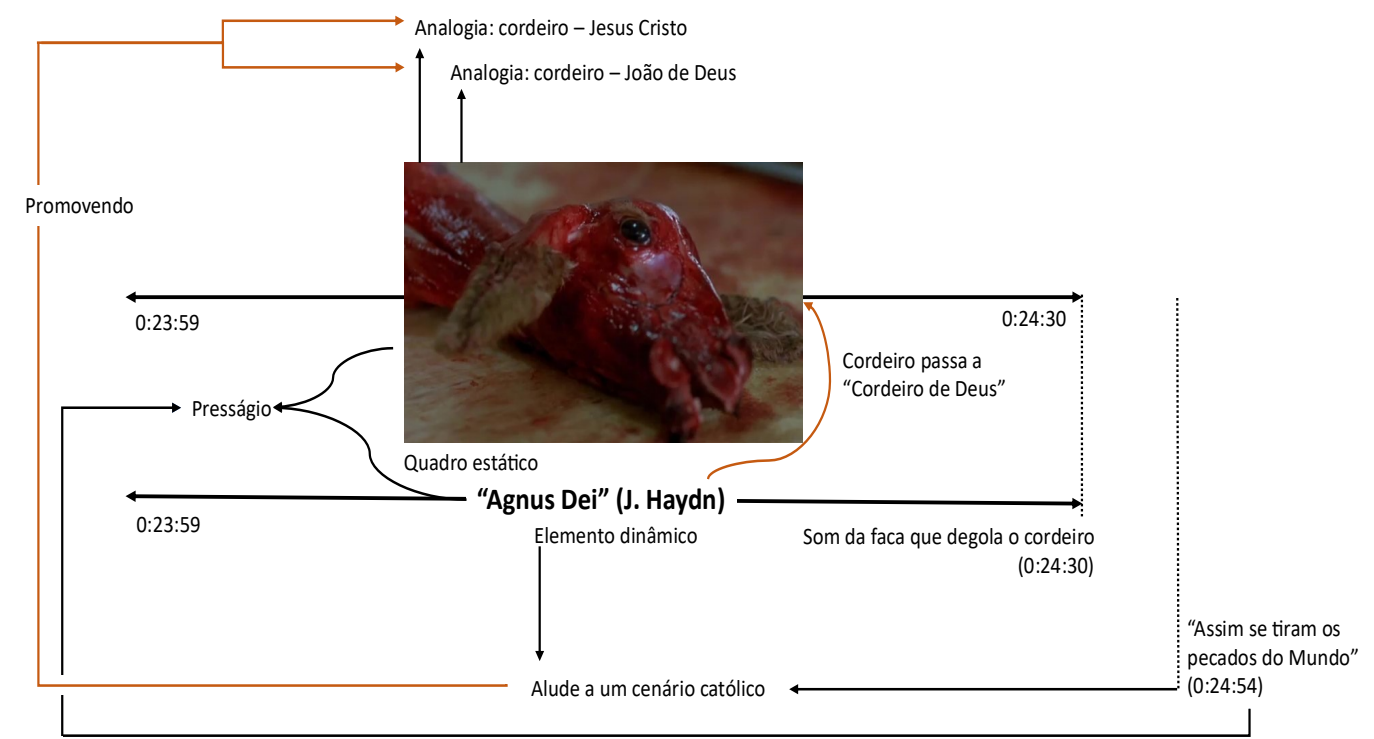

Gráfico 3 - Relação música - sagrado na cena com João de Deus e pai de Joaninha no talho de A Comédia de Deus.

As referências musicais litúrgicas retornam com o aparecimento de Joaninha, nomeadamente, no final da Cerimónia Champanhesa, de novo com uma Missa de Haydn, esta dedicada a São João de Deus. Ouve-se o "Benedictus" da missa que começa com uma melodia apresentada pelo órgão e acompanhada pelas cordas. A simplicidade do acompanhamento evidencia o gesto melódico e resulta numa pequena massa sonora condizente com o estado emocional de Joaninha, que abre a mesa-espelho calmamente para brincar com os berlindes. Evocase, através do timbre característico do órgão e da clareza da melodia e do acompanhamento, uma pureza associada ao caráter onírico da personagem feminina. Após essa secção musical introdutória, inicia-se uma alternância da parte solista entre o órgão e a voz de uma soprano que, com o seu timbre essencialmente agudo, enfatiza a jovialidade e, quiçá, uma sacralidade angelical que se transfere para a cena. A meio da cena, vê-se o gelado chegar e Joaninha pergunta a João de Deus (que está fora de campo) se este é o "paraíso". No plano musical, ouve-se o final de uma parte solista vocal (compasso 26) em que se cantam as palavras do texto litúrgico "Benedictus qui venit in nomine domini" (bendito o que vem em nome do Senhor). Já não é só a personagem Joaninha que é sacralizada nesta cena. É também a criação de João de Deus, o gelado "paraíso", feito a partir do leite que banhou Joana. João 
de Deus transforma a matéria da jovem em gelado na sua procura pelo melhor "perfume", chama-lhe paraíso e enfatiza essa relação onírica e sagrada com os dois personagens da cena, também revelada pela música.

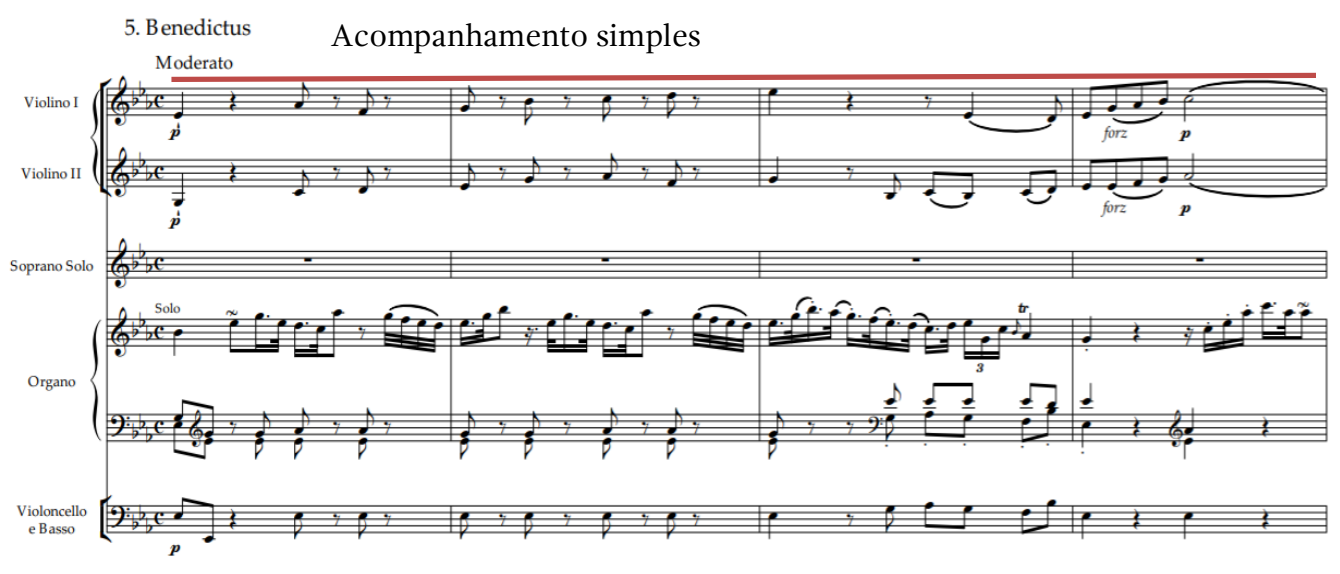

Exemplo 6 - Joseph Haydn, Missa Brevis Sancti Joannes de Deu (c. 1774),"Benedictus", compassos 1 a 4. Calebe Barros (ed.), s.d. Início do elemento musical.

A música de Haydn, neste caso, marca a natureza sagrada do ritual que o protagonista pratica em honra de Joaninha, mesmo que este tenha conotações eróticas evidentes. Em contraste com essas conotações, a música surge como oficializadora do caráter religioso da cerimónia, afastando-a do sexual carnal, para se aproximar do erótico contemplativo. Como defende Giarrusso, "[o] erotismo confunde-se com o religioso numa constante tensão em relação ao objeto de desejo: o corpo feminino, tão harmonioso e divino aos olhos de João de Deus que este lhe celebra a beleza quase como se se tratasse de uma visão celestial" (Giarrusso 2013, 242). Liliana Navarra, escrevendo sobre o feminino na Trilogia de Deus, refere o desejo do realizador de "ilustrar a especificidade da sexualidade elevada à sacralidade" (Navarra 2013, 5). Este elemento musical vem conferir à cena esse caráter sagrado através do contexto religioso a que está associado. Outro aspeto interessante é, como nos anteriores exemplos, a escolha da parte litúrgica a apresentar, neste caso, o "Benedictus". Surge, então, um texto de agradecimento e louvor a Cristo, neste caso personificado por João de Deus, oficiador do ritual e gerente d'O Paraíso. 


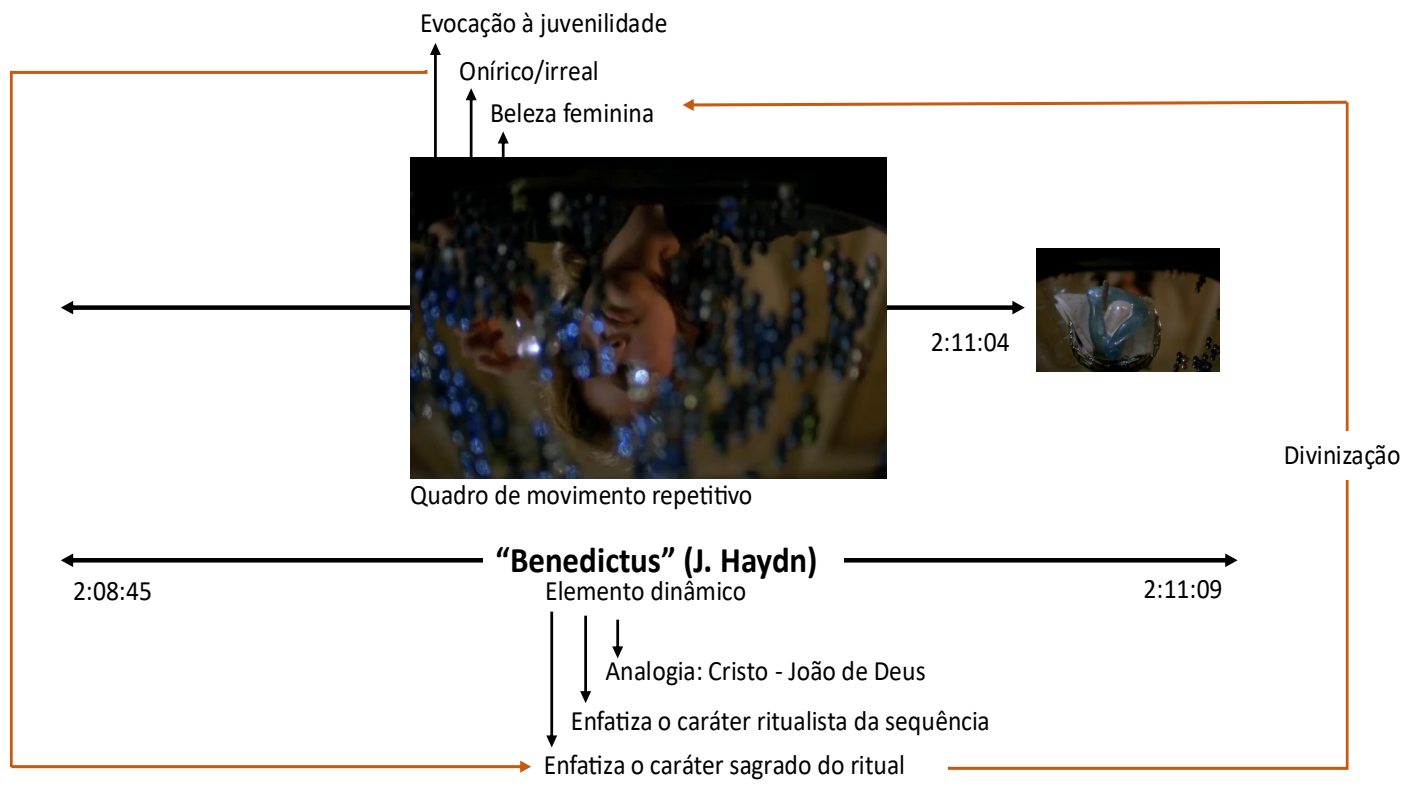

Gráfico 4 - Relação música-sagrado no final da Cerimónia Champanhesa de A Comédia de Deus.

Na última sequência do filme, João de Deus retorna a casa, onde se ouvem os pássaros, que remetem o espectador/ouvinte para a realidade aterradora do filme The Brids (1965), de Alfred Hitchcock, ${ }^{7}$ e o "Terramoto", último andamento d'As Sete últimas palavras de Cristo de Joseph Haydn (2:38:12 - 2:39:48). ${ }^{8}$ O elemento musical começa quando, em grande plano, surge o "Livro de Pensamentos" queimado na fogueira, o ápice da destruição do protagonista, mais uma vez motivada pela expressão máxima de liberdade pela qual tanto zelava. $\mathrm{O}$ "Livro de Pensamentos" é essa mesma expressão - expressão da liberdade de pensamentos, liberdade sexual e social, quase anárquica, na qual pretende viver João de Deus. As partes orquestrais começam em simultâneo e mantêm-se assim durante todo o andamento. Os ritmos em figuras rápidas, num andamento prestíssimo e "con tutta la

\footnotetext{
${ }^{7}$ Como refere Bénard da Costa, "os pássaros de Hitchcock são os últimos que velam com ele, antes da imagem se cerrar na imagem mais terminal que o cinema já me deu” (Costa, s/d, 107). García Manso também salienta a alusão a este filme, referindo, especificamente, a relação entre a cena d'A Comédia de Deus e o momento em que Melanie Daniel e a família Brenner abandonam a quinta sob a presença inquietante de um bando de aves (García Manso 2012, 156).

${ }^{8}$ Existem várias versões desta obra, nomeadamente para orquestra, para orquestra e coro, e para quarteto de cordas. A versão que se ouve no filme é só para orquestra (1786), dirigida por Jordi Savall, como o realizador explicita nos créditos finais do filme.
}

aniki Ensaios | Essays 
forza", enfatizam ainda mais o caráter tempestuoso do elemento musical que encontra na massa sonora poderosa, nas notas alcançadas através de glissandos e nas dinâmicas fortes um meio para a expressão de um "terramoto", como nos indica o título. Assim, passa-se para a imagem todo o caráter desastroso e, em simultâneo, agitado e o plano visual estático configura-se emocionalmente intenso, enfatizando a destruição e a ruína. Poucos segundos após o término do andamento, o plano muda para os créditos finais.

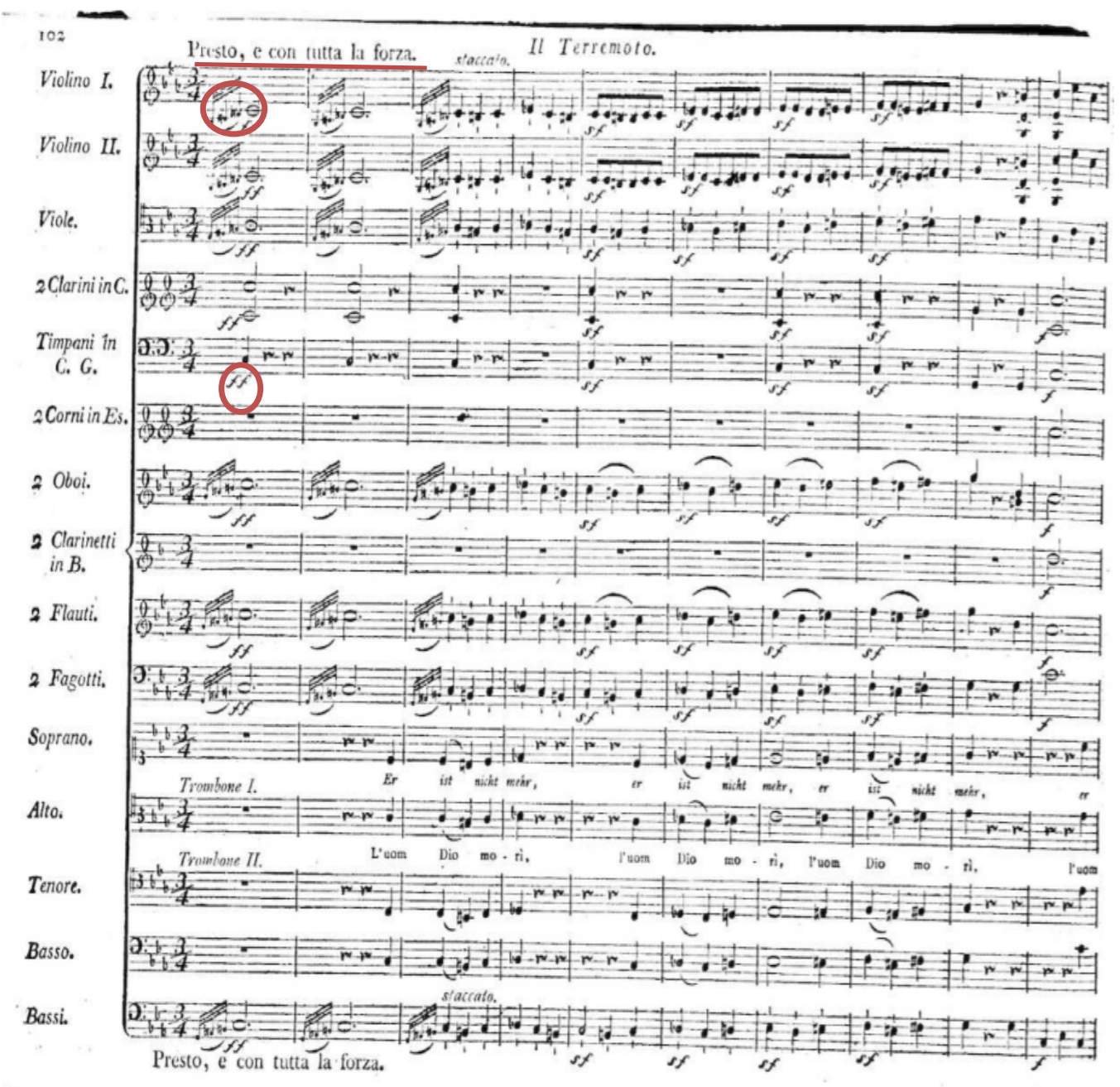

Exemplo 7 - Joseph Haydn, As sete últimas palavras de Cristo (1801), "Terremoto", compassos 1 a 10. Leipzig: Breitkopf und Härtel, s.d. Versão para coro e orquestra. 
Este elemento musical, com óbvias conotações religiosas, ouve-se quando João de Deus olha para os restos do seu "Livro de Pensamentos" na lareira e corrobora as palavras de Camacho Costa que associam a sacralidade, em Monteiro, não apenas à criação, mas também à destruição (Costa 2016, 2). Neste momento em que a vida burguesa do protagonista fica reduzida a escombros, volta a haver uma ascensão ao sagrado através da referenciação musical religiosa que, desta vez, alude, ela mesmo, à destruição. Retornam as referências a Cristo e à sua relação com João de Deus, como disserta Camacho Costa:

como um Cristo martirizado, vítima das proibições que ousou transgredir, não se privando à supremacia do desejo, João abandona o plano, e condena-nos a ficar, a vê-lo sem ele e em silêncio. (Costa 2016, 66)

Esta relação, baseada na partilha do estatuto do transgressor e até, em última instância, do mártir, pode constituir também uma crítica à Igreja Católica, crítica essa que Paulo Cunha encontra em vários momentos da Trilogia, assim como a crítica "à subjugação cega e dogmática do Homem a Deus" (Cunha 2010, 55). Para Giarrusso, é o elemento musical desta cena "que confirma definitivamente o fim do reino de Deus" (Giarrusso 2013, 205), conferindo-lhe, por isso, não só a responsabilidade de sacralizar a cena, mas também uma responsabilidade narrativa - a confirmação máxima da degradação do protagonista que após a ascensão do primeiro para o segundo filme, se encontra, de novo, à margem da sociedade, dada a reprovação dos seus atos por parte da mesma.

aniki Ensaios | Essays 


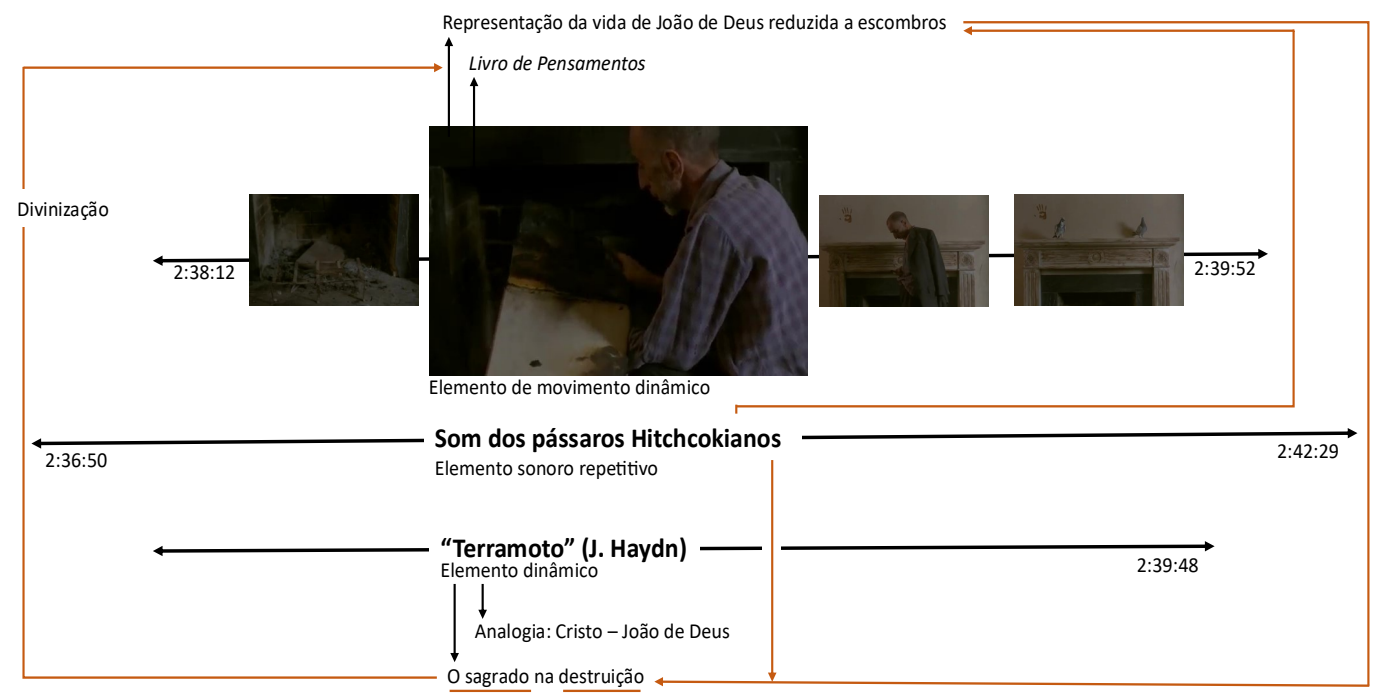

Gráfico 5 - Relação música-sagrado na cena 23.1 de A Comédia de Deus.

\section{As Bodas de Deus}

No filme As Bodas de Deus, o protagonista ascende socialmente com a apropriação de um título nobiliárquico e, com este, intensifica-se a sacralização do personagem que já nos outros filmes era evidenciada pelo seu nome próprio e pela sua proximidade com o criador do universo onde habita. Barão de Deus eleva-se, então, a divindade, aclamada por vários personagens, como é evidente em vários momentos da narrativa. Entre eles, o mais claro talvez seja o do golpe de estado na ópera, em que o público e os atores pedem uma tirania regida pelo protagonista. Também nas cenas passadas no convento, em vários momentos surge a confusão entre o Deus católico a que os meninos e as freiras rezam e João de Deus, que se mantém de pé diante de uma plateia de freiras ajoelhadas.

No final do almoço de João de Deus e irmã Bernarda (Manuela de Freitas), na cantina do Convento, os meninos juntam-se em coro para cantar um hino de ação de graças, surgindo, de novo, a ambiguidade entre João de Deus e o Deus católico. Na imagem anterior, vê-se a irmã Bernarda e João de Deus a fumarem um charuto após uma refeição abastada ter sido desperdiçada por ambos. Este Deus constitui uma crítica direta à igreja e à hipocrisia no respeito dos valores por ela pregados. Sobre esta cena, Camacho Costa refere que "[se] agradece 
[sic] a Deus, o que se desperdiça em abundância e a canção obscena de João é irrisoriamente seguida pelo hino de acção de graças, associandose, como em $O$ Último Mergulho, o divino ao corporal, ao sexual e à alimentação" (Costa 2016, 69). Ora, vemos então nesta cena os valores católicos retorcidos de forma a enquadrarem a sacralização do que é sagrado para César Monteiro - a transgressão.

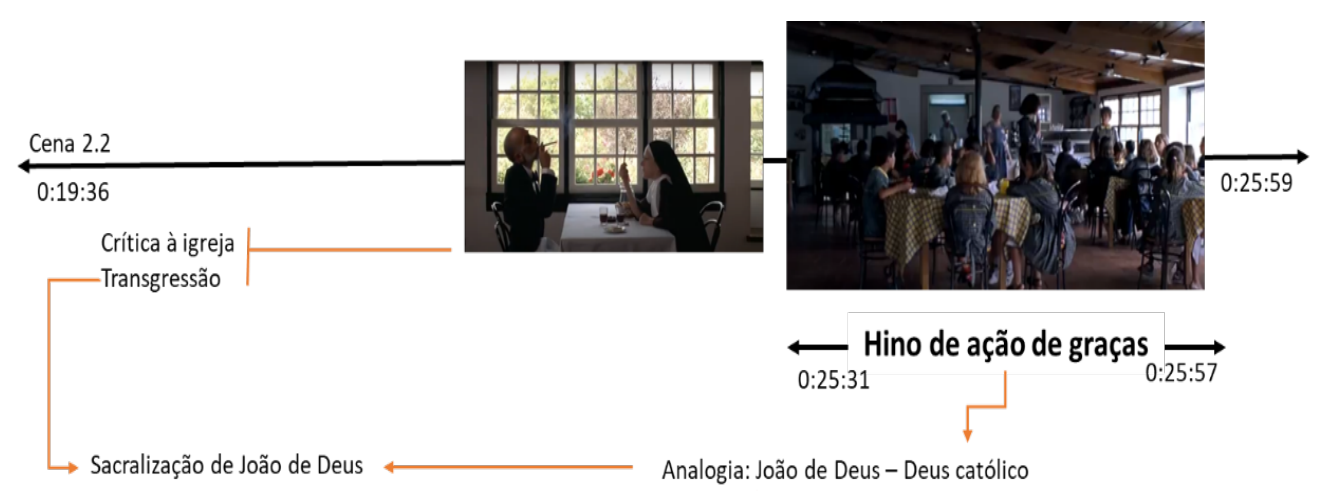

Gráfico 6 - Relação música-sagrado na cena do almoço de irmã Bernarda e João de Deus de As Bodas de Deus.

A figura da mulher, como também nos outros dois filmes, tem um papel de grande destaque n'As Bodas de Deus e constitui-se como uma representação de figura sagrada, divinizada por João de Deus através de vários rituais. Joana (Rita Durão) surge no começo deste terceiro filme a ser salva das águas e mantém-se leal a João de Deus, seu salvador, e com o qual estabelece uma relação de devoção mútua, alteridade que seria consumada com um casamento, como o título deixa explícito, casamento esse que acaba por não existir. Na cena após o almoço entre irmã Bernarda e João de Deus, "vagarosamente, vemos Joana sair do escuro e descer os degraus, como uma luz vinda do breu" (Costa 2016, 70). É sobre esta cena que se ouve a Messe pour les Couvents de François Couperin (0:25:59 - 0:28:55). A imagem atribui à personagem conotações sagradas através da criação de um cenário onírico que transparece através do movimento de câmara, da inexplicabilidade do aparecimento da personagem e do seu surgimento de uma porta desconhecida de um interior desconhecido. Embora a obra musical seja uma referência ao rito católico, outras referências evocam a mitologia grega, com Joana a personificar Perséfone a descer as escadas para o 
mundo inferior, governado por Hades, aqui personificado por João de Deus. Qualquer uma destas referências aponta para um sagrado sobrehumano que paira sobre João de Deus, como nos exemplos anteriores, mas também, e neste caso mais pelo protagonismo visual que tem, sobre Joana que desce do cimo das escadas para o encontrar.

Do título da obra musical deduz-se o contexto onde seria interpretada. Denominada Messe propre pour le couvents de religieux et religieuses, e incluída na compilação Pièces d'orgue, composta por esta e pela Messe pour les paroisses e publicada no final do século XVII (Tunley 2016, 50). Com este contexto, enfatiza-se, ainda mais, a conotação sagrada e religiosa do elemento musical. Também a referência mencionada por Jean Narboni ao quadro Madonna del Parto, de Piero della Francesca, reforça essa relação de Joana com o sagrado através da analogia entre Joana e a Virgem Maria (Narboni 2004, 274). Neste elemento temos, então, a sacralização da figura de Joana, complementada pela mise-enscène, pelo movimento de câmara e por um cenário onírico evocado pela referência à mitologia grega. O simbolismo relacionado com a escadaria é muito associado à frase latina Gradus ad Parnasum, referência da mitologia grega que aponta para uma subida gradual até ao reino do sagrado (termo também usado para simbolizar o crescimento e aumento gradual do conhecimento). Joana espera pacientemente no topo das escadas, pelas quais a câmara sobe lentamente e, assim, a personagem, finalmente, torna-se sagrada através da sua posição no espaço de ação.

A utilização deste excerto musical em particular faz notar a decisão de usar exclusivamente o timbre do cromorne sobre este plano visual. Este timbre muito característico, amadeirado, e facilmente identificado como palheta dupla, cria uma atmosfera sonora que evoca a sacralidade do momento e da personagem Joana. Também o andamento lento da secção da missa e a pequena massa sonora conseguida através de uma harmonia de registo pouco amplo e com poucas notas duplicadas alude à pureza e simplicidade da personagem, qualidades muito apreciadas pelo realizador para criar um ambiente sagrado. $O$ estilo fugado e os gestos melódicos das várias vozes, que são essencialmente ascendentes ou descendentes por graus conjuntos, remetem para essa mesma simplicidade e, também, para o vagar do travelling inicial, que alude ao trajeto lento e sofredor até ao "parnassum". Esta cena antecipa a frase proferida por João de Deus no final do filme: "Oh Joana, que estranho caminho tive de percorrer para chegar junto de ti” (2:18:40 - 2:22:46). 
A interação entre a música, a imagem e a narrativa constrói esse encontro entre as duas cenas e faz deste primeiro momento uma premonição do trajeto de João de Deus até reencontrar Joana no final do filme.

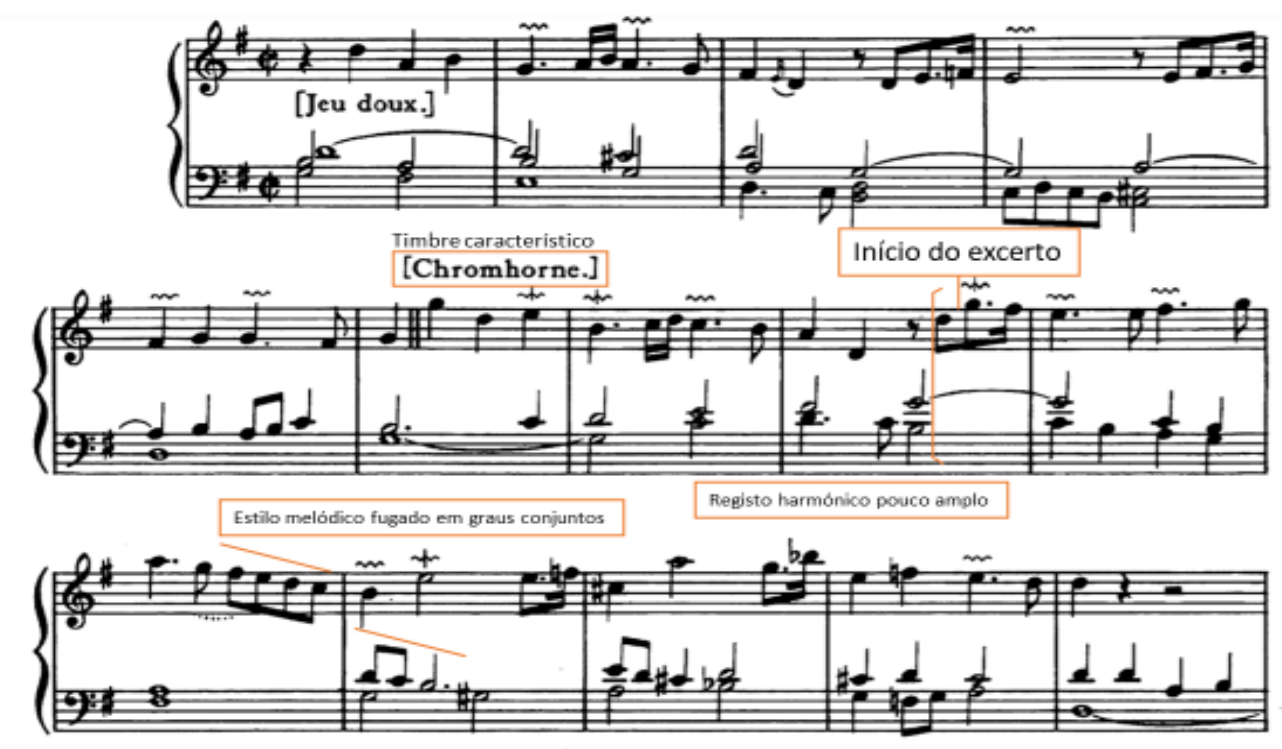

Exemplo 8 - François Couperin, Messe propre pour les couvents de religieux et religieuses (1690), "Récit de Chromhorne", compassos 1 a 14. Paris: A. Durand \& Fils, 1903.

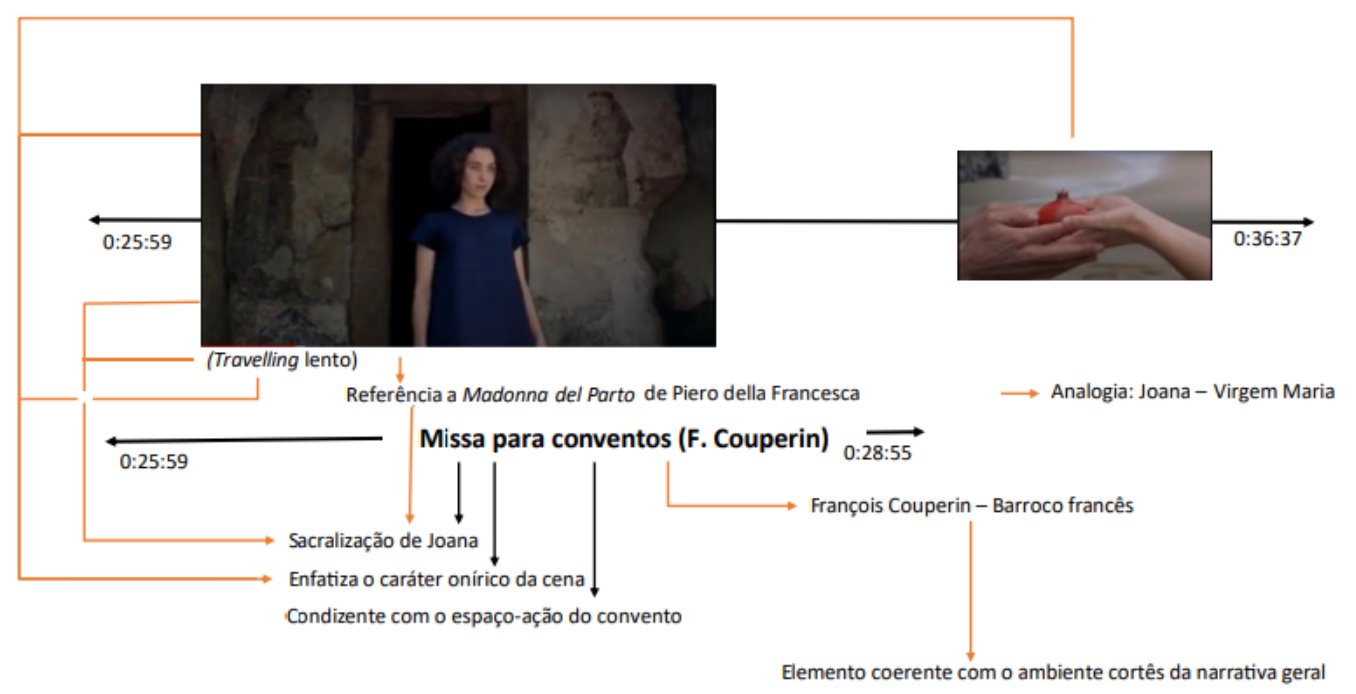

Gráfico 7 - Relação música-sagrado na cena 3.1 de As Bodas de Deus.

aniki Ensaios | Essays 


\section{Conclusão}

A música na obra de Monteiro e o seu caráter pré-existente transportanos para contextos diversos e, por vezes, múltiplos dentro de um único elemento. A referência musical litúrgica, por exemplo, constitui, em Monteiro, ainda que contraditoriamente, uma evocação do sagrado. Sidónio Paes, sobre a poética Cesariana, nota "o fantasma do catolicismo nos seus filmes (já em Veredas, mas sobretudo desde a Casa Amarela), onde as citações da Bíblia e da doutrina cristã, ditas ou contraditas, são o pão nosso de cada dia" (Paes 2005, 44).

Através do estudo de caso, na base deste artigo, concluiu-se que a presença do sagrado nestes três filmes de César Monteiro é conseguida através da articulação dos vários elementos fílmicos, incluindo os elementos sonoros e musicais. Com isto, percebe-se a importância deste tipo de elementos que, embora insuficientemente estudados em detalhe, servem decisivamente a configuração da narrativa. Além disso, notámos uma articulação dos elementos para criar uma determinada configuração emocional em diversas cenas. O caráter hierático e/ou onírico referido acima é alcançado, dentre outras formas, através de características musicais dos elementos que remetem para uma sensação meditativa no espectador/ouvinte. Esta sensação contribui para o realizador não só referenciar o sagrado, mas também, de uma forma muito particular, o alcançar. Através da reflexão, imergimos no universo de João de Deus, transgredimos o nosso universo e com a transgressão, alcançamos “o sagrado”, na aceção de César Monteiro.

Em suma, esta representação do sagrado por meio de referências musicais religiosas está presente através de dois modelos distintos de conceptualização. Por um lado, temos o seu protagonismo - através da referência à religião, sacraliza-se momentos e personagens. Nota-se esta relação, essencialmente, a nível episódico. Ou seja, apesar de não constituir o tipo de sagrado que caracteriza os filmes em geral, a sua referência serve, naquele momento e naquele espaço de ação, para evidenciar as características sagradas de algo. Por outro lado, temos a subversão da referência religiosa que, apesar de parecer antagónica da ideia anterior, sobrepõe-se a ela em certos momentos. Esta subversão vai de encontro a uma ideia geral de sagrado na Trilogia. O sagrado como transgressão está na base da criação dos três filmes e do protagonista João de Deus. Destruindo a representação máxima do sagrado na nossa realidade, o universo da Trilogia distancia-se dela e, assim, sacraliza-se a ele e aos que nele habitam.

aniki Ensaios | Essays 
A música remete para o sagrado, não só através do seu caráter referencial, mas também através de características musicais particulares. A abordagem às referências religiosas como forma de tratar o sagrado é apenas um de vários modos possíveis de encarar a interação música-sagrado na Trilogia de Deus. Apesar de, neste artigo, também refletirmos acerca das características musicais presentes em cada um dos exemplos, valeria a pena, em trabalhos futuros, abordar de forma mais sistemática o significado emocional dos elementos musicais da Trilogia.

\section{Referências}

Areal, Leonor. 2011. Cinema Português: Um país imaginado. Vol. 2. Lisboa: Edições 70.

Buhler, James, David Neumeyer, e Rob Deemer. 2009. Hearing the Movies: Music and Sound in Film History. Nova York: Oxford University Press.

Caillois, Roger. 2001. Man and the Sacred. Illinois: University of Illinois Press.

Chion, Michel. 1994. Audio-Vision: Sound on Screen. Traduzido por Claudia Gorbman. Columbia: Columbia University Press.

Costa, João Bénard da. 2005. “César Monteiro: depois de Deus.” Em: João César Monteiro, organizado por João Nicolau, pp. 381-403. Lisboa: Cinemateca Portuguesa-Museu do Cinema.

. s/d. “A Comédia de Deus: Genérico e análise.” Em: Textos $C P, 105-7$. Centro de documentação da Cinemateca Portuguesa, Pasta 66.

Costa, Pedro Ruas Camacho. 2016. Do Cineasta Demiurgo: Uma análise da obra de João César Monteiro. Dissertação de mestrado. Lisboa: Faculdade de Letras da Universidade de Lisboa.

Cunha, Paulo. 2010. "Decadência, regeneração e utopia em João César Monteiro.” P: Portuguese Cultural Studies 3: 43-60.

García Manso, Angélica. 2012. "La comedia e Dios (A Comédia de Deus, 1995).” Em: Y Dios creó el cine, organizado por Angélica García Manso, pp. 123-177. Cáceres: Norbanova. 
Genette, Gärard. 1997. Palimpsests: Literature in the Second Degree. Lincoln: University of Nebraska Press.

Giarrusso, Francesco. 2013. O Regime Dialógico na Obra de João César Monteiro: Matérias e conteúdos de uma prática subversiva. Tese de Doutoramento, Lisboa: Faculdade de Ciências Sociais e Humanas-Universidade Nova de Lisboa.

Maia, Catarina. 2013. "A Linguagem e os ritos sacrificiais no cinema de João César Monteiro." Revista da Filosofia e da Imagem em Movimento 4: 97-115.

Monteiro, João César. 1974. "O Passado e o Presente.” Em: Morituri Te Salutant (Os que vão morrer saúdam-te), organizado por João César Monteiro, pp. 33-43. Lisboa: Arcádia. . 2005a. "O Sagrado e o Profano: O Último Mergulho (Entrevista com João César Monteiro por Rodrigues Silva).” Em: João César Monteiro, organizado por João Nicolau, pp. 352-67. Lisboa: Cinemateca Portuguesa-Museu do Cinema. . 2005b. “Um cineasta na cidade’: Entrevista com João César Monteiro por Jean A. Gili.” Em: João César Monteiro, organizado por João Nicolau, pp. 410-416. Lisboa: Cinemateca Portuguesa-Museu do Cinema.

Narboni, Jean. 2004. "Les exercices spirituels, et autres, de João César Monteiro.” Em: Pour João César Monteiro: contre tous les feux, le feu, mon feu, organizado por Ludovic Colin e Fabrice Revault d'Allonnes, pp. 271-282. Crisnée, Belgique: Yellow Now.

Navarra, Liliana. 2013. João César Monteiro entre Antropologia e Ficção. Tese de Doutoramento. Lisboa: Faculdade de Ciências Sociais e Humanas-Universidade Nova de Lisboa.

Nicolau, João, org. 2005. João César Monteiro. Lisboa: Cinemateca Portuguesa - Museu do Cinema.

Nogueira, Isabel. 2010. “A imagem cinematográfica em João César Monteiro: recordações da casa amarela, crítica, abstracção e empatia." Revista Estudos do Século XX 10: 205-11.

Paes, Sidónio. 2005. "Recordações de João (de Deus) César Monteiro." Em: João César Monteiro, editado por João Nicolau, João César Monteiro, João Bénard da Costa, e António Rocha. Lisboa: Cinemateca Portuguesa-Museu do Cinema. 
Pinto, José. 2021. A Música e o Som na Trilogia de Deus de João César Monteiro. Dissertação de mestrado. Lisboa: Faculdade de Ciências Sociais e Humanas - Universidade Nova de Lisboa.

Tunley, David. 2016. François Couperin and "The Perfection of Music". Aldershot: Ashgate.

\section{Filmografia}

As Bodas de Deus. Dir. João César Monteiro. Madragoa Filmes, Radiotelevisão Portuguesa (RTP) (coprodução), Gemini Films (coprodução), Instituto Português da Arte Cinematográfica e Audiovisual (IPACA) (participação), Portugal, 1999. 147mins.

A Comédia de Deus. Dir. João César Monteiro. G.E.R. (Grupo de Estudos e Realizações), Pierre Grise Productions (coprodução), Zentropa Productions (coprodução), Mikado Film (coprodução), La Sept-Arte (coprodução), Eurimages (suporte), Portugal, 1996. 162 mins.

Nosferatu, Eine Symphonie des Grauens. Dir. Friedrich Wilhelm Murnau. Prana-Film, Alemanha, 1922. 94mins.

Recordações da Casa Amarela. Dir. João César Monteiro. Invicta films, Portugal, 1989. 117mins.

The Birds. Dir. Alfred Hitchcock. Universal-International Pictures, Estados Unidos, 1963. 119mins.

\section{Partituras}

Antonio Vivaldi, Stabat Mater (c. 1727), "Stabat Mater Dolorosa". Andreas Schein (ed.), 1997.

Claudio Monteverdi, Vespro della Beata Vergine (1610), "Domine ad adiuvandum”. Philip Legge (ed.), 2006.

Joseph Haydn, Missa Sanctae Caeciliae (1811), “Agnus Dei”. Leipzig: Breitkopf \& Härtel, s.d..

Missa Brevis Sancti Joannes de Deu (c. 1774), "Benedictus". Calebe Barros (ed.), s.d. 
. Die sieben letzten Worte unseres Erlösers am Kreuze

(1801), "Il terremoto". Leipzig: Breitkopf und Härtel, s.d. (Versão para coro e orquestra).

\section{Music and the Sacred in João César Monteiro’s Deus Trilogy}

ABSTRACT This article addresses the presence of the sacred in the "Deus trilogy" directed by João César Monteiro, and the way that presence is articulated through religious musical elements and references. The notion of cinema as sacred, i.e. as opposed to the profane and consequently to "our" world, has clear implications in the work of João César Monteiro. The way in which the sacred is reached is noticeable in the various elements that constitute the "media hybrid" that is the movie. The musical presence in the "Deus trilogy" becomes one of the tools that the director uses to achieve or at least to refer to the sacred in his movies. This article analyses some of the twisted religious references through which César Monteiro seeks, not the catholic sacred, but another kind of sacred, one developed through values that Catholicism actually condemns. The main hypothesis defended is that the sacred in the "Trilogy" develops, or at least part of it, through religious musical references - by one side through the contextual space where they stand and by the other side through the subversion of that same space. By analysing examples, we intend to develop this hypothesis with arguments related to the interpretation of visual, narrative and mainly musical elements.

KEYW ORDS Music and cinema; sacred; João César Monteiro; religious music.

Recebido a 30-03-2021. Aceite para publicação a 03-11-2021.

aniki Ensaios | Essays 